\title{
THE CASE FOR EQUITABLE TRANSIT-ORIENTED DEVELOPMENT \\ EXPLORING THE LINK BETWEEN HOUSING AFFORDABILITY AND TRANSIT ACCESSBILITY IN BURNABY, BRITISH COLUMBIA
}

\author{
By
}

Amanda Mackaay

Bachelor of Arts in Political Science, University of British Columbia, 2012

\author{
A Major Research Paper \\ presented to Ryerson University \\ in partial fulfillment of the requirements for the degree of \\ Master of Planning \\ in \\ Urban Development
}

Toronto, Ontario, Canada, 2018

(C) Amanda Mackaay 2018 


\section{Author's Declaration for Electronic Submission of a MRP}

I hereby declare that I am the sole author of this MRP. This is a true copy of the MRP, including any required final revisions.

I authorize Ryerson University to lend this MRP to other institutions or individuals for the purpose of scholarly research.

I further authorize Ryerson University to reproduce this MRP by photocopying or by other means, in total or in part, at the request of other institutions or individuals for the purpose of scholarly research.

I understand that my MRP may be made electronically available to the public. 


\title{
THE CASE FOR EQUITABLE TRANSIT-ORIENTED DEVELOPMENT
}

\section{EXPLORING THE LINK BETWEEN HOUSING AFFORDABILITY AND TRANSIT ACCESSBILITY IN BURNABY, BRITISH COLUMBIA}

(C) Amanda Mackaay, 2018

\author{
Master of Planning \\ in \\ Urban Development \\ Ryerson University
}

\begin{abstract}
Transit-oriented development (TOD) is a planning model that concentrates compact, mixed-use development near high order transit. The problem arises when the intensification of transit-oriented locations does not occur in an equitable way and results in the displacement of low-income households, who are arguably the most reliant on access to transit.

Metro Vancouver's regional growth strategy (RGS) supports the TOD model by designating Urban Centres as key areas to absorb the majority of the region's growth and development, as well as transit service. The growth targets in the RGS have led to the rezoning of many Urban Centres to allow for more density, thereby prompting redevelopment activity. The City of Burnaby is of particular interest because it has been experiencing a significant loss of affordable rental housing in low-income neighborhoods along the SkyTrain line as a result of the redevelopment occurring within its designated Urban Centres. This research provides a list of recommendations that are geared toward helping Burnaby preserve affordable rental housing options along the transit corridor.
\end{abstract}

Key words: Affordable Rental Housing, Density, Displacement, Low-Income Household, Redevelopment, Regional Growth Strategy, Town Centre, Transit Accessibility, Transit Corridor, Transit-Oriented Development, Urban Centre 


\section{Acknowledgements}

I would like to extend my appreciation to my supervisor David Amborski, for all the guidance and advice you provided throughout this whole process. You helped me push past my uncertainty about challenging the status quo, which I am very grateful for.

Thank you to my second reader, Randy Hodge, for your thoughtful and thorough feedback. Your expertise on the subject matter really helped to elevate my paper to the next level.

Thank you to my friends for lifting me up and making those long days at the SLC so much more bearable. I feel so grateful to have shared this journey with such an intelligent and inspiring group of people. To Olivia, Alison and Steve, thank you for making my experience in Toronto so fun and memorable.

To my parents, Hans and Sherryl, thank you for your continuous love and encouragement. You have always supported me in my decisions to pursue my dreams, even if it has meant that I had to move away. I have learned so much from you about perseverance - thank you for leading by example. To my brother, Ryan, thank you for making me laugh and for your words of encouragement during this experience.

And a very big thank you to Jason for diving head first into this adventure with me. I am so grateful for the unwavering love and support you have given me throughout this whole roller coaster ride - you are my rock. 


\section{Table of Contents}

1.0 INTRODUCTION................................................................................................................... 1

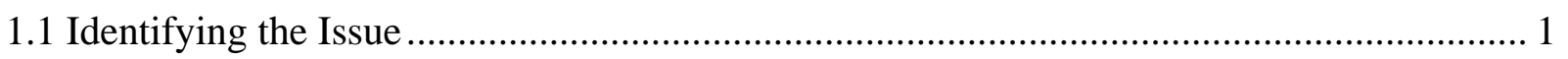

1.2 The Importance of Affordable Purpose-built Rental Housing ............................................... 4

1.3 The Connection Between Housing Affordability and Transit Accessibility.......................... 6

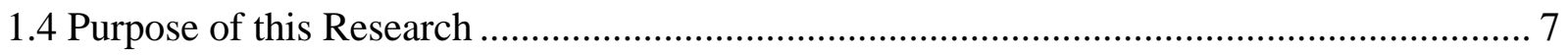

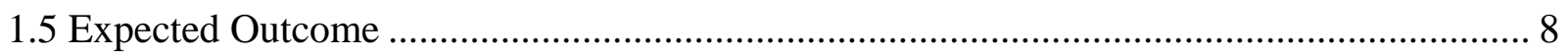

2.0 METHODOLOGY ............................................................................................................................ 9

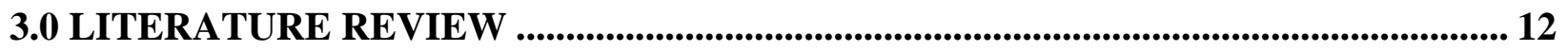

3.1 Setting the Context: The History of the Canadian Rental Housing Landscape .................. 12

3.2 Key Actors in Affordable Rental Housing Provision in British Columbia......................... 15

3.3 Transit-Oriented Development and the Metro Vancouver Policy Framework .................... 18

3.4 The Distinction Between Purpose Built Rental Housing and Affordable Rental Housing. 22

3.5 The Impact of Transit Accessibility on Housing Affordability for Renters ....................... 23

3.6 Growth Versus Affordability: The Loss of Affordable Rental Housing in Burnaby.......... 25

4.0 EVALUATION OF CURRENT HOUSING TOOLS USED BY BURNABY ................. 29 5.0 CASE STUDIES: METRO VANCOUVER MUNICIPAL HOUSING POLICIES AND

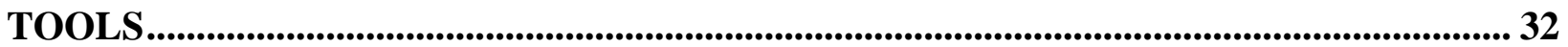

5.1 Richmond's Inclusionary Zoning Policy and Affordable Housing Reserve Fund.............. 32

5.2 Vancouver's Rental Housing Stock Official Rate of Change Policy ................................... 35

5.3 New Westminster's Secured Market Rental Housing Policy............................................... 37

5.4 Burnaby’s Cedar Place: Public-Private Partnership ............................................................ 38

6.0 CASE STUDIES: U.S. HOUSING POLICIES AND TOOLS............................................. 41

6.1 Seattle's Multifamily Property Tax Exemption Program …………………………............. 41

6.2 Massachusetts Smart Growth Zoning Overlay District Act................................................ 44

6.3 San Francisco Bay Area Transit Oriented Affordable Housing Fund ................................. 46

6.4 U.S. Low Income Housing Tax Credit............................................................................. 49

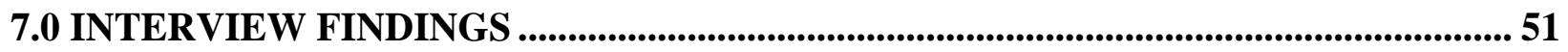

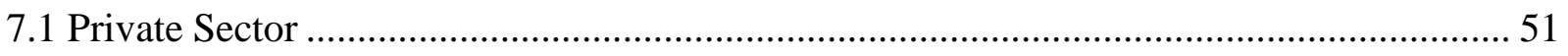

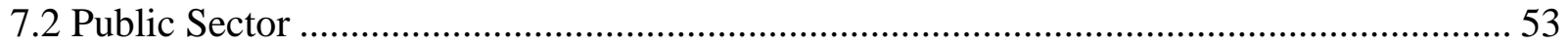


8.0 SUMMARY OF FINDINGS .......................................................................................................... 56

9.0 DISCUSSION AND RECOMMENDATIONS......................................................... 58

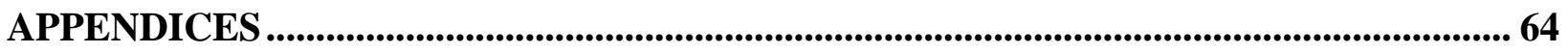

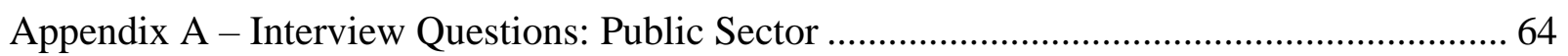

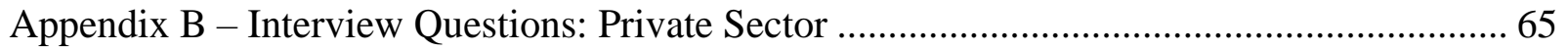

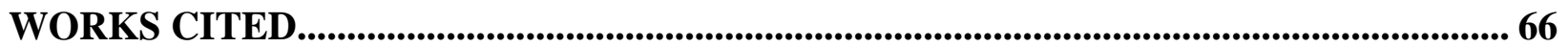




\section{List of Figures}

Figure 1: Burnaby within Metro Vancouver.......................................................................... 1

Figure 2: Total Net Change in Apartment Rental Units in Metro Vancouver from 2010-2017..... 2

Figure 3: Purpose-built Rental Housing Starts versus Condominium Starts in Burnaby ............... 4

Figure 4: Urban Centres in relation to the Frequent Transit Network ......................................... 20

Figure 5: Metro Vancouver's Frequent Transit Network ........................................................... 24

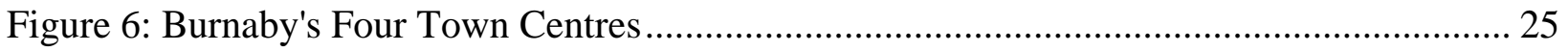

Figure 7: Supplementary Base and Bonus Density Permitted by 's' zoning ............................... 28

Figure 8: New Westminster Zoning Bylaw Requirements for Parking versus Metro Vancouver's

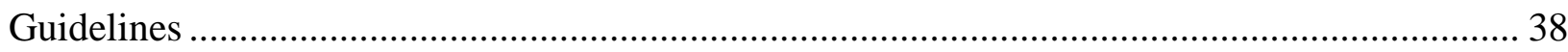




\subsection{INTRODUCTION}

\subsection{Identifying the Issue}

There are two distinguishing features that characterize the Metro Vancouver region: an attractive yet constrained physical geography, and high housing prices. The region is bound by mountains to the north, the Pacific Ocean to the west and the U.S. border to the south, which present physical barriers to development. Furthermore, the region's Urban Containment Boundary aims to concentrate $98 \%$ of regional growth within its designated boundaries by the year 2041, thereby placing limits on where growth and development can occur (Metro Vancouver, 2014). The restricted supply of available land, coupled with substantial demand from both residents and foreign investors, have placed an upward pressure on housing prices in many municipalities in the region. The City of Burnaby is an inner-suburban municipality within Metro Vancouver that directly borders the City of Vancouver, the region's business and financial center. Given its proximity to the City of Vancouver, Burnaby also grapples with significant housing affordability challenges.

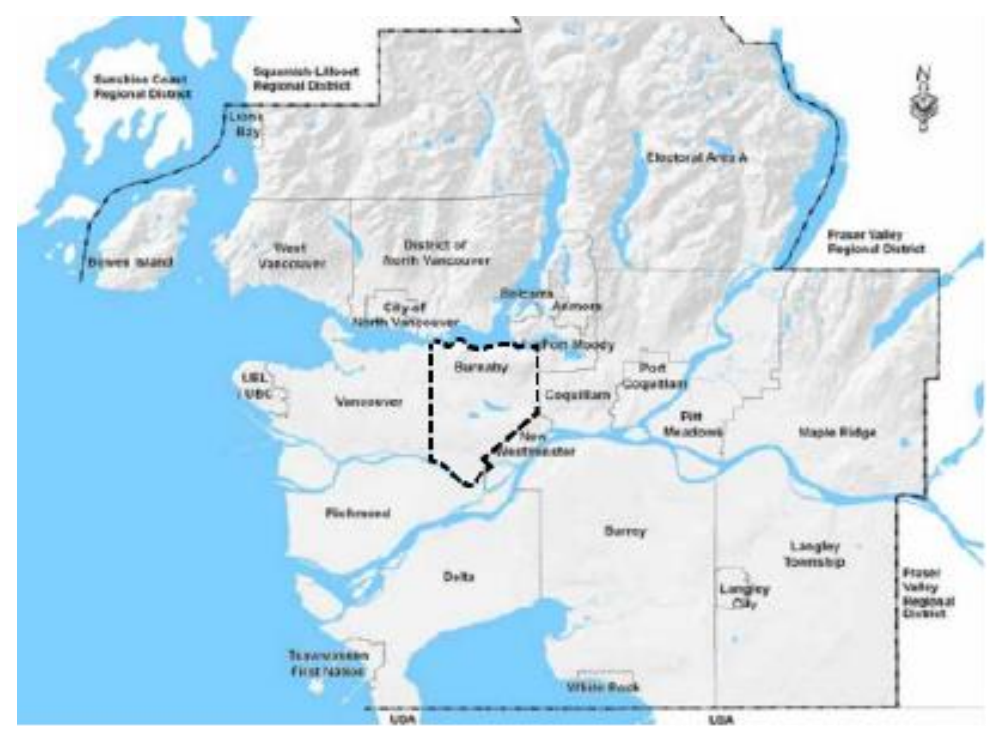

Figure 1: Burnaby within Metro Vancouver (Source: Metro Vancouver, 2015) 
Burnaby is the third most populous municipality in the region, with a 2016 census population of 232,755 (Statistics Canada, 2017). This number will increase significantly over the next few decades as the City is expected to absorb $10 \%$ of the region's population growth by the year $2041^{1}$ (Metro Vancouver, 2015). This population growth will inevitably be accompanied by increased demand for housing. However, the City has found it challenging to provide enough supply to keep pace with demand, thereby perpetuating the rise in housing prices. This discrepancy between supply and demand is a trend that is not unique to Burnaby, yet the City differentiates itself from its Metro Vancouver counterparts with the disproportionately large number of rental apartment demolitions that have occurred over the past seven years. Between 2010 and 2017, Burnaby has suffered a net loss of 688 rental units (Figure 2) and has experienced difficulty constructing new affordable units to offset this loss.

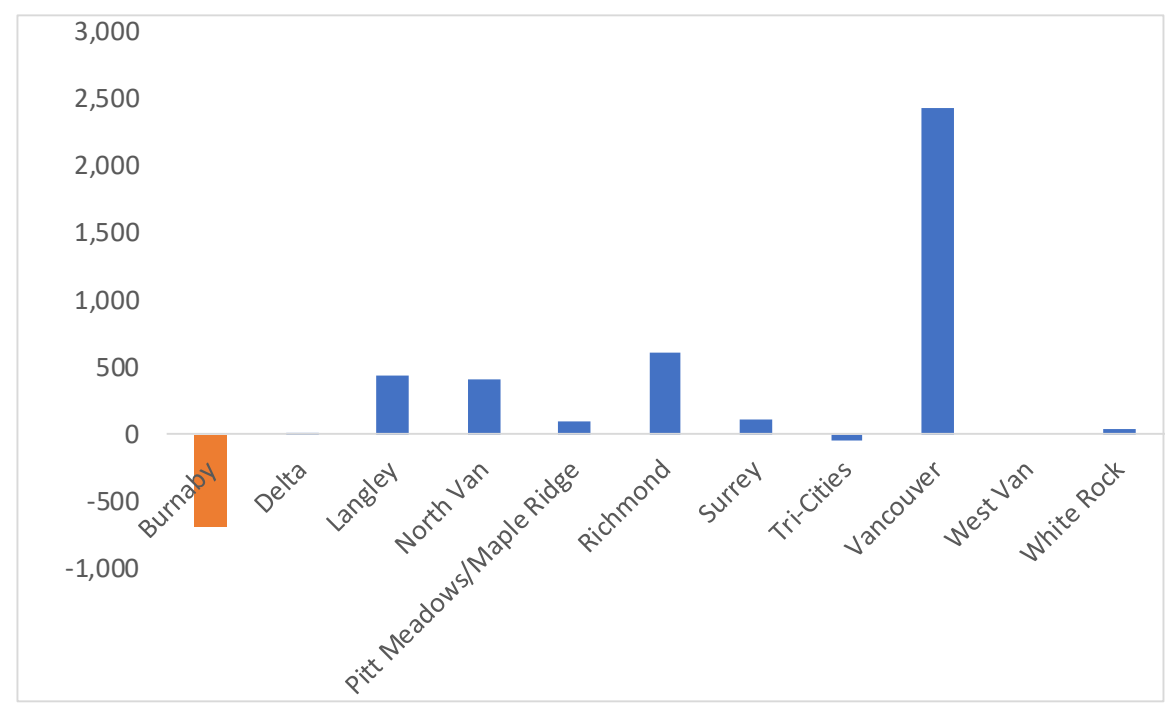

Figure 2: Total Net Change in Apartment Rental Units in Metro Vancouver from 2010-2017 (Data Source: CMHC Rental Market Survey)

\footnotetext{
${ }^{1}$ Metro Vancouver's regional growth strategy outlines the growth projections for the region and each member municipality until the year 2041 .
} 
Most of the demolitions are occurring in Burnaby's Town Centres, which contain a significant amount of the City's low-rise, affordable rental stock. This is because the Town Centres have been identified as areas that are ripe for growth under Metro 2040: Shaping Our Future, the regional growth strategy, due to their proximity to the SkyTrain, the region's high order rail system. The RGS has designated all transit-oriented locations in the region as Urban Centres, with the expectation that they will absorb a large majority of the growth in each respective municipality.

This push for densification along the region's transit corridor is a manifestation of the transit-oriented development (TOD) goals of the RGS. The TOD model is predicated on the creation of dense, mixed-use communities in areas that are well serviced by transit (Jones and Ley, 2016). While the smart growth objectives of the RGS offer a progressive vision for the trajectory of growth and development in the region, it is important to consider the unintended consequences of this model. Much of the literature on TOD contends this model of development is associated with increased land values (Quigley 2010; Jones, 2014; Jones and Ley, 2016). High land values often result in the redevelopment of transit-oriented neighborhoods, thereby increasing the risk of displacement for low-income households (Quigley 2010).

This is exactly what has been occurring in Burnaby as a result of the RGS. Burnaby has responded to the call for intensification by rezoning the Town Centres for more density, thus prompting significant redevelopment in these areas. This strategy, however, is based on a planning rationale that is driven primarily by density targets, with meager regard for the affordability concerns that follow. The crux of the issue is that growth along Burnaby's transit corridor has occurred at the expense of low-income renters who rely heavily on living in close 
proximity to high order transit. They are being forced out of their neighborhoods due to the redevelopment of the existing affordable apartment rentals into high-density condominiums.

\subsection{The Importance of Affordable Purpose-built Rental Housing}

"For the City to achieve its vision for a healthy, livable and complete community, residents must have a selection of attainable housing options." (City of North Vancouver)

As housing prices continue to outpace household incomes, the cost of homeownership has become increasingly out of reach for many residents in Metro Vancouver. Consequently, demand for housing has shifted heavily toward renting, thus putting pressure on the minimal amount of available rental stock. In the case of Burnaby, new rental housing starts have been disproportionately low compared to condominium starts over the past ten years due to the fact that private developers are the primary builders of housing in Canadian municipalities (Figure 3). The preference for condominium construction is rooted in the fact that these projects offer a more certain return on investment compared to rental developments.

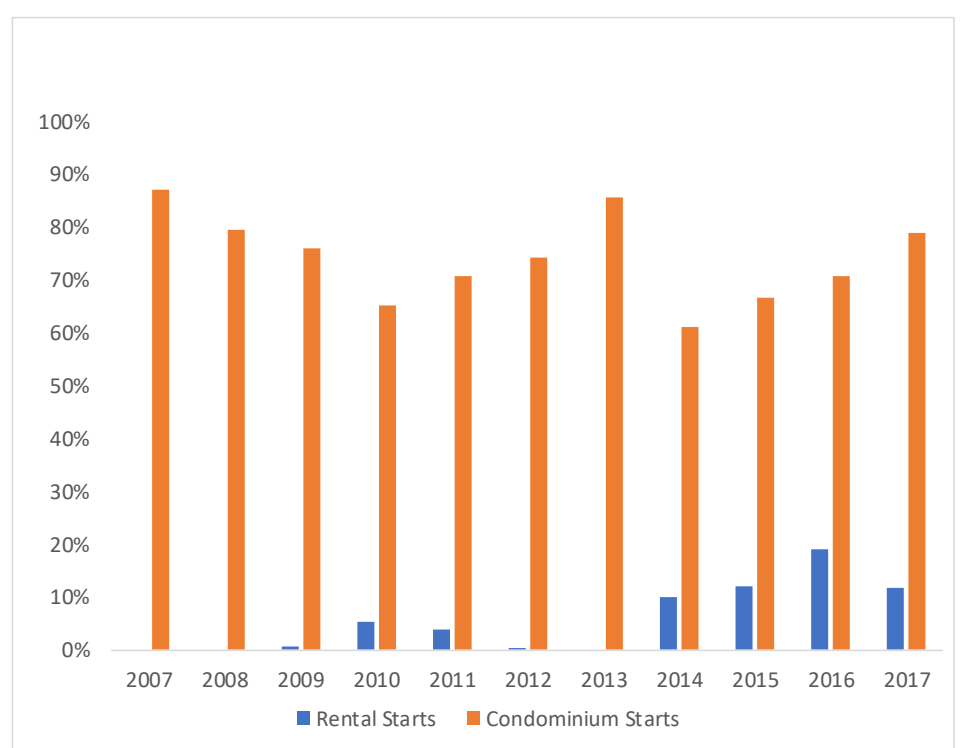

Figure 3: Purpose-built Rental Housing Starts versus Condominium Starts in Burnaby (Data Source: CMHC Rental Market Survey) 
However, current market conditions in Burnaby have resulted in the appreciation of housing prices, therefore market-based condominiums tend to be out of reach for many residents. Approximately $25 \%$ of the region's condominium stock have been rented out as part of the secondary rental market in 2017 (CMHC, 2016). However, it should be noted that this type of housing is more precarious as it does not offer the same security over tenure that is provided by purpose-built rental housing. Since each condominium rental is owned by an individual investor, the certainty that the unit will remain as a rental following the expiration of the lease agreement is dependent on the objectives of the owner. Should they choose to sell or move into the unit, the unit will subsequently be removed from the rental universe.

Affordable purpose-built rental housing plays an important role in meeting the needs of a diverse and growing population. Vibrant and healthy communities are predicated on the inclusion of residents from different socio-economic backgrounds. It is therefore important that cities encompass a diversity of housing options to cater to the various needs of the population. Ensuring that the housing stock is inclusive of affordable rental housing options is seen as a catalyst in economic productivity as it affords households the ability to relocate to areas that offer strong employment opportunities (Pomeroy, 2015). Mixed-income housing also reduces poverty concentration and provides meaningful opportunities for residents to come together to share ideas and experiences (Quigley, 2010).

According to the CMHC 2017 Rental Market Report, the vacancy rate in Burnaby decreased to $0.6 \%$ while the average rent rose to $\$ 1,189$, which represents an increase of $7.1 \%$ from 2016 (CMHC, 2017). The downward trend in the vacancy rate combined with increasing average rents in Burnaby is indicative of a discrepancy between supply and demand of purposebuilt rental housing. Approximately $40 \%$ of households in Burnaby identify as being renters 
(Statistics Canada, 2017), which highlights the need to add more rental options to the City's housing stock.

The Metro Vancouver Housing Data Book revealed that according to the 2016 census, of those who identify as renters in Burnaby, 39\% are very low-income households and $23 \%$ are low income households (Metro Vancouver, 2018). However, high land and construction costs serve as barriers to the feasibility of constructing housing that caters to the needs of lower income households (Metro Vancouver, 2016). This suggests that innovative strategies and creative partnerships are needed to encourage the development of rental housing that reaches deeper levels of affordability.

\subsection{The Connection Between Housing Affordability and Transit Accessibility}

Housing affordability cannot be considered in insolation of transit accessibility. The preservation of affordable housing in neighborhoods that are well-serviced by transit is important because it enables access to essential services such as healthcare, education, and employment (Quigley, 2010).

However, as previously noted, the desirability of transit-rich areas often results in an increase in property values which leads to the transformation of existing low-rise neighborhoods into high-density developments. The problem arises when the redevelopment around transit stations does not preserve affordable rental options to allow people of all incomes to share in the benefits that come with living in mixed-use, transit-oriented communities.

A cost-burden study done by Metro Vancouver indicates that renter households earning less than $\$ 50,000$ per year are the most reliant on transit to get to work or to access community services and amenities (Metro Vancouver, 2016). These are households that Metro Vancouver defines as being within the very low and low-income categories (Metro Vancouver, 2015). However, the estimated gap between the projected supply and demand of rental housing between 
2017 and 2026 for these sub-groups is 23,750 units (BC Non-Profit Housing Association, 2017).

This discrepancy between demand and supply indicates that current municipal incentives geared toward encouraging more rental housing are not providing housing for those in greatest need. This bolsters the idea that more needs to be done to ensure that affordable housing preservation tools and policies are in place to address the important connection between housing affordability and transit accessibility. This paper will explore the relationship between housing and transit in greater detail in the literature review.

\subsection{Purpose of this Research}

A review of existing literature supports the relationship between transit-oriented development and the gentrification of low-income neighborhoods along the SkyTrain corridor in Vancouver (Jones, 2014; Jones and Ley, 2016). Currently there is no literature that specifically focusses on addressing the unique challenges that the City of Burnaby grapples with, thereby making this research both timely and important.

The goal of this research is to establish a list of feasible and actionable recommendations that are capable of encouraging growth along the transit corridor in a way that preserves affordable rental housing options for low income households in Burnaby. It should be noted that affordable housing preservation extends beyond the physical unit and refers to preserving the ability for people of all income levels to live in an area where they can access employment opportunities and essential services (Quigley, 2010).

This paper will attempt to fill the assessed gaps in research by answering the following questions:

1. What are the best practices for integrating affordable rental housing into the transitoriented development model that can be applied to Burnaby? 
2. How can the City of Burnaby balance growth objectives with housing affordability goals?

3. What role should each level of government play in the preservation of affordable rental housing along the transit corridor?

\subsection{Expected Outcome}

The redevelopment activity occurring in Burnaby's Town Centres is putting the City's affordable rental stock in a very precarious position. The root of the problem stems from the difficult task of encouraging intensification as specified by the regional growth strategy while also addressing the need to promote housing affordability.

The relationship between housing affordability and access to transit is topical as many municipalities across Canada are looking to densify around transit corridors. It is therefore important to explore the tools and policies that can be employed to ensure the transit-oriented development (TOD) model is inclusive of affordable rental housing options. It is expected that this research will add value to the broader conversation that is currently playing out surrounding the equitable TOD. 


\subsection{METHODOLOGY}

The goal of this research paper is to formulate a list of recommendations that can be used to help Burnaby preserve and construct affordable rental housing along the SkyTrain line. The research questions outlined in this paper will be informed by a combination of different methodological approaches: a comprehensive literature review, an analysis of precedents in Metro Vancouver and the U.S., as well as semi-structured interviews with Burnaby planning staff and private developers.

The research paper will start with a review of existing academic literature. The purpose of the literature review is to set the conceptual framework that will guide the research process. The literature review will first set the context by looking at the history of rental housing policy in Canada. This will be accompanied by an overview of the level of involvement of different actors in housing provision in British Columbia.

It is important to situate the research in the context of the regulatory regime in Metro Vancouver. A scan of relevant policies and programs that have an influence on TOD and housing affordability will help to identify opportunities for encouraging equitable TOD as well as the barriers that impede Burnaby from achieving this goal. Furthermore, the literature review will explore the relationship between housing affordability and transit accessibility as it provides a rationale for the need to incentivize the provision of equitable TOD. A review of Burnaby's policy framework and existing market conditions will lay the foundation for what is possible within the municipal context.

The case study review will first evaluate the different tools and policies that are being employed in various Metro Vancouver municipalities to preserve the affordable rental housing stock. The rationale for using local municipalities as precedents is to identify best practices that are located within the same regulatory climate as Burnaby. These municipalities are also subject 
to the same growth targets under the RGS, therefore it is useful to analyze innovative strategies that are being used to balance density with affordability. The assessment of other municipal tools and policies will help to ground the recommendations in the Metro Vancouver context.

Case studies from the U.S. were also assessed as part of this research. San Francisco and Seattle were chosen because both cities share Burnaby's struggle to provide affordable rental options. These precedents will offer insight into innovative strategies that could be replicated in the Canadian context. Massachusetts was selected to offer an example of upper government involvement in affordable housing policy development. The U.S. Low Income Housing Tax Credit was assessed to demonstrate the role that federal tax incentives can play in making affordable housing projects more feasible. These strategies will be evaluated through the lens of British Columbia's legislative context to ensure their applicability to Burnaby.

Open ended interviews with key stakeholders that are involved in housing provision in Burnaby were also conducted as part of this research. The sample included Burnaby planning staff and private developers. The goal of the interviews was to garner the professional opinion of different stakeholders on the opportunities and challenges surrounding affordable rental housing integration into TOD in Burnaby. The interview questions were designed to be open ended to allow each participant to offer additional information that may be pertinent to the topic. Analysis of interview results will provide an understanding of which tools and policies will be the most viable for all concerned stakeholders.

All research was aggregated and analysed to identify key takeaway points. This synthesis of significant findings informed the creation of six recommendations that will assist Burnaby in preserving and adding to the stock of affordable rental housing along the transit corridor. 


\section{Glossary}

This research is based on Metro Vancouver's (2015) definitions of the following terms:

Affordable Rental Housing: Housing that is built by the private sector. Rents are offered at below market rates through a government subsidy or incentive to the private sector. This housing targets households that earn between $50 \%$ and $80 \%$ of the reginal median income.

Low Income Households: Households that earn between $50 \%$ and $80 \%$ of the regional median income.

Market Rental Housing: Housing that is built by the private sector and offers rents at the market rate. This housing targets households that earn above $80 \%$ of the regional median income.

Non-Market Rental Housing: Housing that is built using federal and provincial programs and is managed by the non-profit sector and cooperative housing agencies (Metro Vancouver, 2018). This housing includes social, public, non-profit and co-op housing. This housing targets households that earn below $50 \%$ of the regional median income.

Very Low-Income Households: Households that earn below 50\% of the regional median income. 


\subsection{LITERATURE REVIEW}

\subsection{Setting the Context: The History of the Canadian Rental Housing Landscape}

It is important to contextualize the vulnerability of affordable rental housing in terms of the political landscape in Canada. Between 1950 and 1970, all levels of governments played an active role in the construction of affordable housing for segments of society that were excluded from the private housing market (Carter, 1997). Following the end of World War Two, Canadian cities experienced a wave of immigration as well as an increase in the number of families, which inevitably fuelled demand for more affordable housing options, particularly rental housing (McClanaghan \& Associate, 2010).

In response to the changing socio-demographic fabric of Canadian cities, the federal government offered tax incentives to private developers to catalyze the construction of purposebuilt rental housing, which resulted in a $110 \%$ increase in the supply of total rental housing stock (McClanaghan \& Associate, 2010). The incentives included tax sheltered income on wood frame rental buildings (Clayton, 1998), as well as a "rollover" provision that removed the capital gains tax on rental properties if profits were reinvested into another rental property in the same calendar year (Enemark, 2017). Furthermore, only building materials for rental properties were taxed at the Manufacturers Sales Tax rate of 11\% (Enemark, 2017).

The second wave of government involvement in housing occurred from 1974 to 1986 and was marked by an introduction of more targeted tax incentive programs such as Multiple Unit Rental Building tax shelter (MURBs), Assisted Rental Program (ARP) and the Canadian Rental Supply Program (CRSP) (McClanaghan \& Associate, 2010). These incentive programs were used to maintain a steady supply of rental housing following the introduction of the Condominium Act in the 1970s, which essentially created the condominium form of ownership. 
This period was also defined by a movement away from social housing and toward a more decentralized housing model. This involved joint partnerships between the federal and provincial governments to provide operating subsidies and grants to aid in housing low-income households that were being excluded from the private rental market (McClanaghan \& Associate, 2010). The community-based housing model was also introduced during this time (McClanaghan \& Associate, 2010), which proved to be a more successful way of delivering affordable housing than the traditional social housing model that was predicated on more active government involvement in construction of the units.

There has been, however, a shift in recent decades towards prioritization of the homeowner segment of the market. This shift has manifested itself in government policy, which has served as a catalyst in the decreasing supply of affordable rental housing (Hulchanski, 2004). Following the tax reforms in 1982 that effectively ended the favorable federal tax treatment of rental development, rental housing starts began to decrease and have continued along this downward trajectory. The decrease in tax incentives for rental housing was exacerbated by the proliferation of condominium construction. Given that renter income tends to be less, condominium developers were able to outbid rental developers for available residentially zoned high-density land (Hulchanski, 2004). The erosion of the favorable tax treatment and the introduction of the condominium form of ownership inevitably facilitated the decrease in construction of purpose-built rental housing in Canada.

The federal government continues to play a role in housing delivery by way of joint partnerships with provincial and territorial governments (Metro Vancouver, 2015). Through the Investment in Affordable Housing (IAH) program, the federal government forms funding agreements with provinces and territories which requires them to match the federal contribution 
while also allowing them to retain control over the administration of the funds through their individual programs. The rationale for this is that provincial and territorial governments have a better understanding of the specific housing needs within their respective jurisdictions.

In the $\mathrm{BC}$ context, the federal and provincial governments signed a funding agreement in 2001 with the goal of jointly addressing a wide variety of housing needs in the province. Starting in 2001, a bilateral agreement was signed between the provincial and federal governments which committed both parties to an equal contribution of $\$ 88.7$ million over four years (BC Housing). The goal of this agreement was to create 3,900 units of affordable housing. Both governments signed the "Extension of the Investment in Affordable Housing Agreement" in 2014 which marked an investment of an additional $\$ 150$ million from both parties over five years to assist with the creation of housing for low-income households (BC Housing).

The release of the National Housing Strategy on November 22, 2017 represents a significant commitment from the federal government to take on a leadership role in investing in affordable housing in Canada. The proposed National Housing Co-Investment Fund aims to provide 15.9 billion to repair existing rental housing and to build new affordable housing (CMHC, 2017). Furthermore, the federal government plans to partner with provincial and territorial governments on funding the \$4-billion Canada Housing Benefit (CMHC, 2017). The program is set to launch in 2020 and is estimated to provide vulnerable households an average of $\$ 2500$ per year to assist with housing needs (CMHC, 2017). While the more granular details of the strategy are still tentative, it presents new opportunities for all levels of government to work together to respond to the gap between the demand for affordable housing need and limited supply housing that is being built to adequately house low to moderate income households. 


\subsection{Key Actors in Affordable Rental Housing Provision in British Columbia Federal Government}

The federal government continues to unilaterally deliver affordable rental housing programs through the Canadian Mortgage and Housing Corporation (CMHC). A notable contemporary federal housing program is the Rental Construction Financing initiative, which was started in April 2017. The initiative has $\$ 2.5$ billion to provide to municipalities, the private-sector, and builders, as well as non-profit housing providers in the form of low-interest loans for rental housing development between 2017-2021 (CMHC). In order to be eligible for the loan, the project must have at least five rental units (CMHC). Furthermore, at least $20 \%$ of the units must be rented at a rate that is equal to or below $30 \%$ of the area medium household income, and this level of affordability must be maintained for at least 10 years after the date of first occupancy (CMHC).

\section{$\underline{\text { BC Provincial Government }}$}

In 1993, the housing system experienced the historic devolution of social housing provision from the federal level to the provincial government (Hulchanski, 2004). However, unlike many of its Canadian counterparts, the province of British Columbia retained centralized control over non-market rental housing administration (Schuk, 2009). The province continues to develop, manage, and administer a wide range of housing options for people in need through The British Columbia Housing Management Commission (BC Housing) (BC Housing, 2017).

More specifically, BC Housing has sponsored the Community Partnership Initiative (CPI) since 2001 which seeks to create affordable rental and ownership housing for low to moderate income households through partnerships with non-profit organizations, community organizations and government agencies (BC Housing). BC Housing is the level of government that retains sole responsibility for program funding and will enter into an operating agreement 
with non-profit partners to provide interim construction or take-out financing to either purchase, renovate or construct affordable rental housing (BC Housing). The project partner assumes the responsibility of maintaining the property by funding the necessary upgrades and repairs to the capital items (BC Housing). The CPI program presents an opportunity for constructive partnerships between the province and other actors which can be leveraged to provide necessary affordable rental housing options.

The recent announcement of the 2018 BC Housing Budget promises more investment in affordable rental housing. The province has agreed to invest $\$ 6.6$ billion over the next ten years in affordable housing with the goal of partnering with other actors to add over 114,00 rental units to the provinces housing stock (Province of British Columbia, 2018).

Emphasis should however be placed on the partnership aspect of the provincial government's involvement in housing creation. While the BC government continues to play a role in the provision of affordable rental housing, the construction, maintenance and operation of the physical units still requires involvement from other actors.

\section{Municipal Governments}

The provincial government has granted municipalities more tools and resources with the intention of empowering them to play a more active role in affordable housing provision. Municipalities were granted this authority through amendments to the Local Government Act (LGA) (BC Ministry of Forests and Range Housing Department). For example, under Section 877 of the LGA, municipalities are required to include "local government policies for affordable housing, rental housing and special needs housing" (BC Ministry of Forests and Range Housing Department). Local governments can employ zoning tools, the development approvals process, 
financial incentives as well as leverage their own land and joint-development opportunities to provide affordable housing.

The effectiveness of these tools and initiatives in providing affordable rental housing varies across the different Metro Vancouver municipalities. Burnaby has employed these tools to provide affordable rental housing, however the City has been unable to preserve a sufficient number of affordable units in close proximity to the transit corridor which will be explored later in this paper.

\section{$\underline{\text { Private Sector }}$}

The ability for local municipalities to provide physical units of affordable housing is limited given that their main sources of revenue consists of property taxes and user fees, which they must allocate to a wide variety of community services. As a result, municipalities rely heavily on the private sector to provide much of the housing stock. Private developers are businesses that are motivated by the expected return that a project will generate, and therefore their decisions tend to be more strongly driven by market conditions. As a result, market rentals are rented at rates that seek to cover development costs and adhere to prevailing market trends.

\section{Non-Profit Housing Sector}

The non-profit housing sector plays a role in affordable housing provision by partnering with the private sector and different levels of government to provide affordable rental units. The non-profit sector owns and operates housing at below market rents, sometimes with support from upper-levels of government. To date, there are 2,656 units of non-profit housing in Burnaby's rental stock, with 70\% located in the southern quadrant of Burnaby (City of Burnaby, 2016). However, it should be noted that demand for this housing far exceeds supply. 


\section{$\underline{\text { Financial Institutions }}$}

Financial institutions play a role in providing the capital needed to build new residential developments. However, most private investors require quick, high yield returns (Pollon, 2017), which drives their aversion to take on the risk associated with building affordable rental housing. There are however, lenders that are willing to absorb the risk associated with constructing belowmarket rental projects.

New Market Funds (NMF) is an example of a socially conscious investment firm that partners with non-profit operators to invest in purpose-built affordable rental housing. The firm does not demand the same market rate returns which therefore allows it to fill the investment gap needed to make affordable rental projects more feasible (Pollon, 2017). It partners with investors and foundations who have money but lack capacity to invest in affordable housing. NMF uses its financial and market expertise to invest the capital provided by its various partners into projects that provide long-term community benefits (New Market Funds). The Fund has committed to creating 358 units of rental housing which are expected to be completed in 2018 (New Market Funds). These units will cater to households that make $70 \%$ of the area median income (New Market Funds).

\subsection{Transit-Oriented Development and the Metro Vancouver Policy Framework}

Transit-oriented development (TOD) has emerged as a planning response to the problems associated with suburban sprawl brought on by post-war development (Bernick \& Cervero, 1997). TOD is characterized by the notion of a "transit village" that contains several dense buildings that are near a rail transit station (Bernick \& Cervero, 1997). It is praised for its goal to "create liveable and sustainable communities that limit the need for automobile use, reduce greenhouse gas emission, improve air quality, promote healthier lifestyles, and revitalize 
declining urban areas" (Jones and Ley, 2016). The impetus for the TOD designation is that it offers a signal that the area is an attractive place for redevelopment and investment by virtue of its proximity to a fixed-rail service.

A common theme that is articulated in key Metro Vancouver policy documents is the importance of locating dense, compact urban form in areas that are well-served by transit. Furthermore, there is emphasis placed on the need to ensure these developments are inclusive of affordable housing options, thereby stressing the inextricable connection between affordability and transit.

\section{Metro 2040: Shaping Our Future}

The Metro Vancouver policy framework is predicated on the acceptance that transitoriented development is an adequate framework to encourage sustainable growth and development. As previously mentioned, Metro 2040: Shaping Our Future is the region's growth strategy (RGS) and it is used to guide the trajectory of growth and development in the region until the year 2040. All municipalities in Metro Vancouver ratified the growth plan on March 22, 2011, thus requiring them to develop policies that are aligned with the strategic growth objectives and targets outlined in the RGS. The prioritization of compact, transit-oriented development manifests itself in the various strategies outlined in the RGS. Most notably, Urban Centres are designated as the target areas for growth and transit service. ${ }^{2}$ By the year 2040 , Urban Centres are expected to absorb $40 \%$ of the residential growth in the region and $50 \%$ of the employment (Metro Vancouver, 2015).

\footnotetext{
${ }^{2}$ Under the RGS, Urban Centres are designated as areas that will be the main target for population growth and transit investment. "They are intended as the priority locations for employment and services, higher-density housing, commercial, cultural, entertainment, institutional and mixed-uses" (Metro Vancouver, 2015).
} 


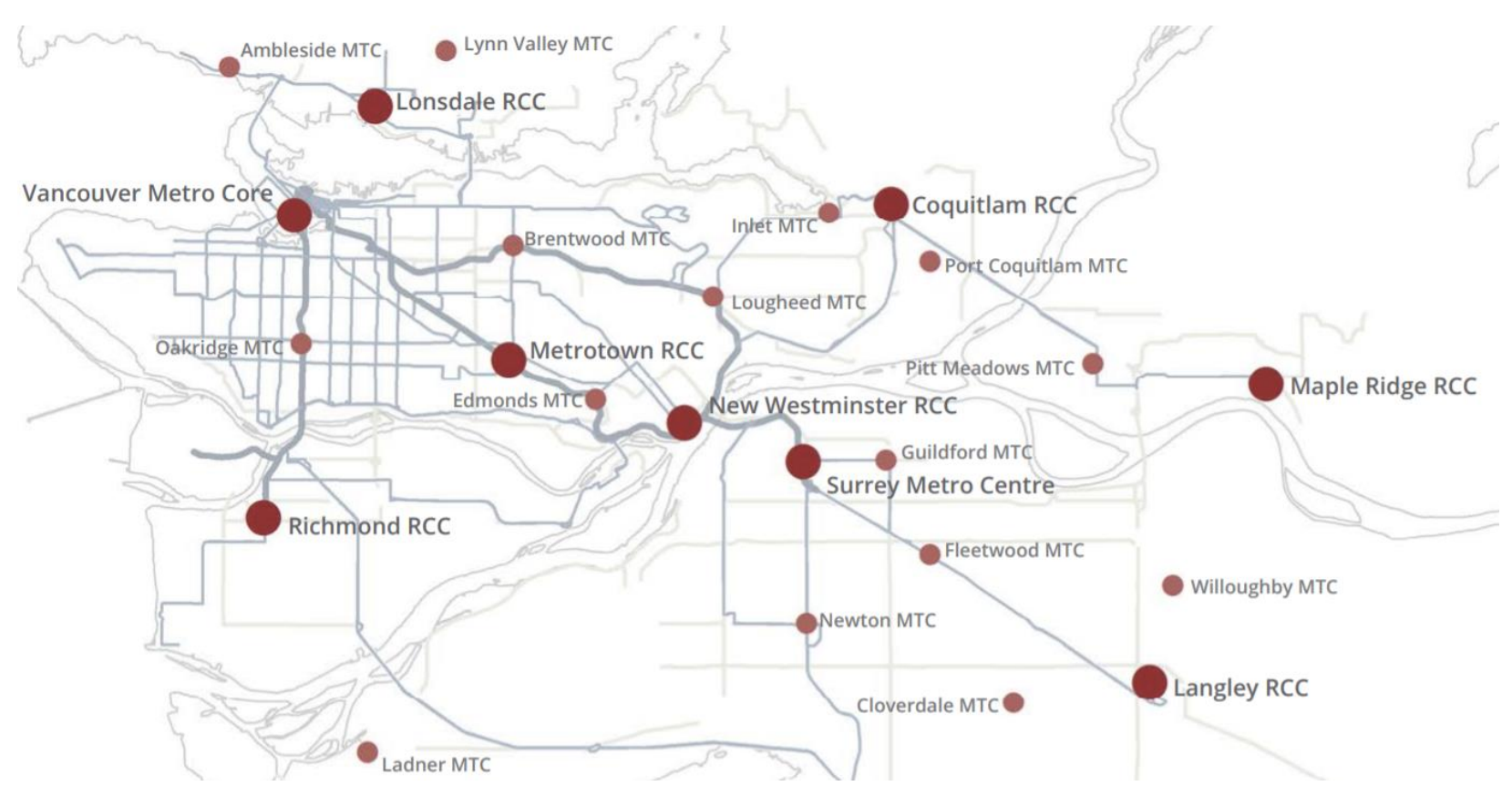

Figure 4: Urban Centres in relation to the Frequent Transit Network (Source: Metro Vancouver, 2015

Subsection 1.2.1 designates Metro Vancouver's role to partner with municipalities, other governments and agencies to explore the use of financial tools and other incentives to support the "location of major commercial, office, retail, and institutional development in Urban Centres" (Metro Vancouver, 2015). Furthermore, section 1.2.2 asserts that municipalities must work with TransLink and other levels of government to deliver regional transportation networks and services that will accommodate the growth and development of Urban Centres and Frequent Transit Development Areas (Metro Vancouver, 2015).

Strategy 4.1 states that municipalities are required to develop policies and strategies to accommodate the projected housing demand. More specifically, municipalities should partner with federal and provincial governments to increase the supply of affordable housing options for low and low-to-moderate income households, which particular emphasis in areas that are serviced by transit (Metro Vancouver, 2015). Furthermore, municipalities are advised to prepare 
Housing Action Plans that specifically speak to provision of new rental housing and mitigating the loss of existing rental housing stock (Metro Vancouver, 2015). Burnaby has committed to developing a Housing Action Plan concurrently with its Official Community Plan (OCP) update.

\section{Regional Affordable Housing Strategy}

The Regional Affordable Housing Strategy (RAHS) is a document that works in conjunction with the RGS to provide a strategic vision and set of recommended action items for addressing housing affordability in Metro Vancouver. One of the key goals set out in the RAHS is to make the transit corridor the focus for new rental and non-market housing locations (Metro Vancouver, 2015). While this policy document provides a list of recommended actions for Metro Vancouver, as well as the three levels of government, TransLink, and other housing stakeholders, it does not outline any prescriptive targets or requirements and instead serves as more of a guide for improving affordability in the region. The ambiguity surrounding the obligation of municipalities raises accountability concerns.

\section{Transport 2040}

TransLink, the transportation authority for the region, has stated in its regional transportation strategy that all transportation investment needs to be supportive of the region's desired land use pattern (TransLink, 2011). It reinforces the goal of the RGS to build high quality transit infrastructure that supports the proposed corridors and centers concept (TransLink, 2011). TransLink's regional strategy is supportive of TOD as it argues that the concentration of highdensity, mixed-use, human scale built form around high order transit stations is necessary to accommodate the region's projected growth in a sustainable way. 


\subsection{The Distinction Between Purpose Built Rental Housing and Affordable Rental Housing}

While the past few decades have been characterized by a significant decrease in purposebuilt rental housing, a combination of low interest rates and high renter demand has contributed to a renewed interest in building this type of housing. Many of the new developments in Burnaby's four Town Centres include new purpose built rental housing units. However, the issue of affordability comes into question when the new units are charging market rents, which are significantly higher than what was being charged for units that were demolished.

The CMHC considers housing to be affordable if a household spends $30 \%$ or less of its before tax income on shelter costs. According to the 2017 CMHC Rental Market Report, the median rent for purpose-built rental housing in Burnaby was $\$ 1,100$ (CMHC, 2017), although many of these units in the new developments are renting for significantly higher. The 2016 census indicates that the median household renter income in Burnaby was $\$ 45,839$ and therefore, using the CMHC affordable definition, monthly rental housing payments must be $\$ 1,146$ or less to be considered affordable (Metro Vancouver, 2018).

The situation is different for very low income and low-income renter households in Burnaby, who have an annual average household income that is under $\$ 35,000$, and between $\$ 35,000$ and $\$ 60,000$ respectively (Metro Vancouver, 2018). This means that an affordable monthly rent must be below $\$ 875$ for very low-income households and between $\$ 875$ and $\$ 1,500$ for low-income households. The difference between the 2017 median rent for purpose-built rentals and the maximum affordable rent payments for lower income households highlights the difficulty associated with the affordability definition. While the rents charged in the new units are affordable for certain household income groups, many low-income households will inevitably be paying more than $30 \%$ of their income on rent. 
The prioritization of high income renter households is incongruent with the housing projections outlined in the RGS which estimates that affordable rental demand will account for approximately 64\% of total rental housing demand in Burnaby by 2021 (Metro Vancouver, 2015). Of the total affordable rental demand, $43 \%$ will come from very low-income households and $21 \%$ will come from low income households (Metro Vancouver, 2015). This brings the ability Burnaby's policy framework to provide housing for vulnerable households into question. While there are programs in place to target very low and low-income households as demand still exceeds supply. Furthermore, they do not specifically support strategies that prioritize the development of affordable rental housing in close proximity to transit.

\subsection{The Impact of Transit Accessibility on Housing Affordability for Renters}

The traditional affordable housing definition considers only shelter costs in the determination of the cost burden for households (Reconnecting America, 2006). The limitations associated with the affordability metric are rooted in the fact that they do not account for the additional costs associated with transportation that inevitably increase the household monthly expenses (Reconnecting America, 2006). Many experts argue that housing can only be considered affordable if a household spends less than $45 \%$ of its pre-tax income on the combined cost of housing and transportation (Litman, 2017). This definition acknowledges that housing is not affordable if it is associated with high transportation costs. The relationship between transit and housing affordability is significant as proximity to fast and frequent transportation plays a vital role in securing access to jobs and other opportunities (Revington and Townsend, 2016). Furthermore, access to the Frequent Transit Network in Vancouver helps to offset the burden associated with living in areas that are characterized by high housing costs. 


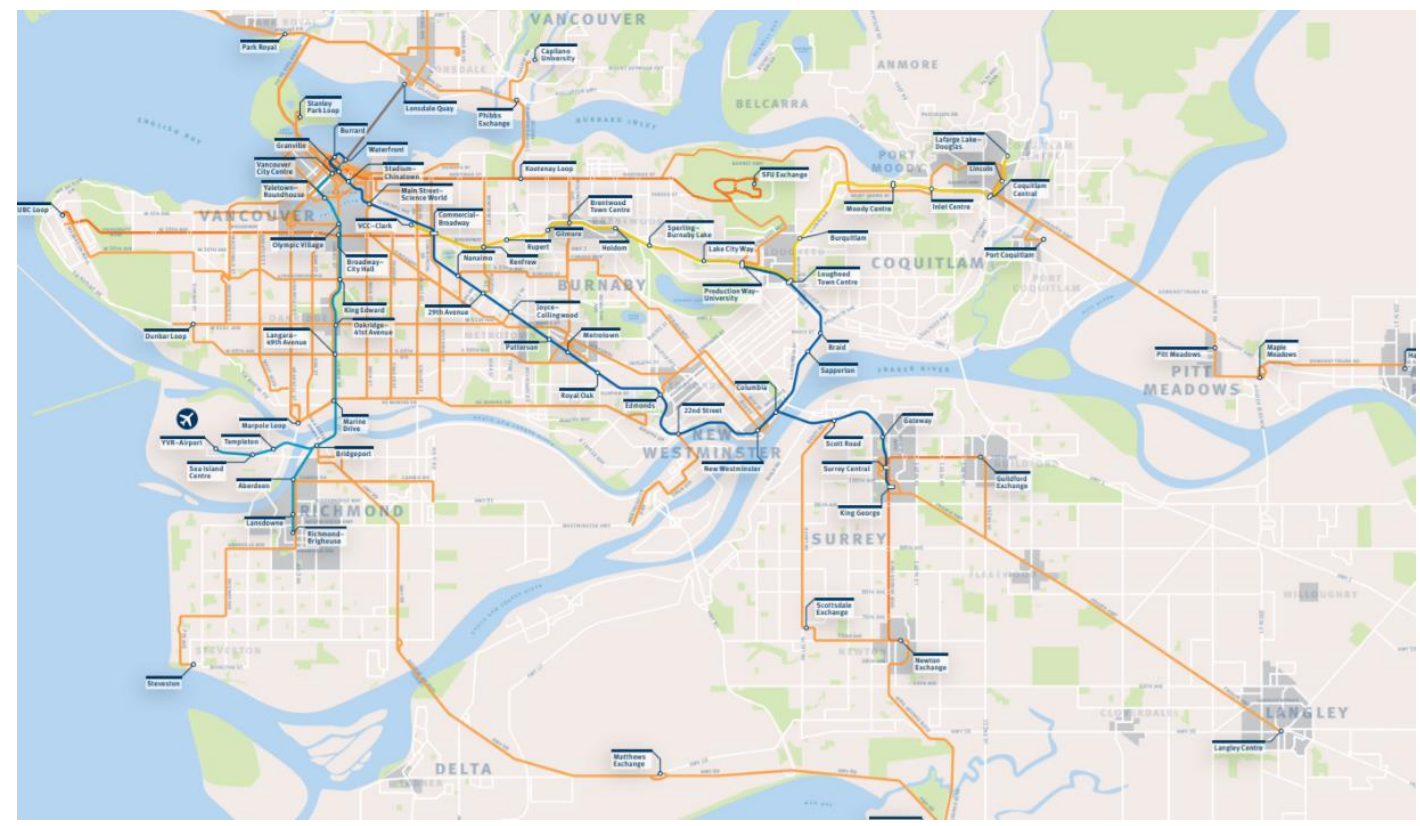

Figure 5: Metro Vancouver's Frequent Transit Network (Source: TransLink)

The Metro Vancouver Cost Burden Study acknowledges that working households face trade-offs. While housing costs may be lower in periphery municipalities in Metro Vancouver, transit service is significantly more limited, thus resulting in higher rates of automobile usage (Metro Vancouver, 2015). Municipalities, such as Burnaby, that are well serviced by the Frequent Transit Network tend to have higher housing prices, which are offset by access to lower cost transportation infrastructure such as transit, walking and cycling. However, the cost burden of living in areas outside of the Frequent Transit Network is much more significant for low and very low-income households as the costs associated with owning and operating a vehicle are greater relative to higher income households. Therefore, living in areas that are well serviced by transit becomes less of a choice and more of a necessity for lower income households.

As previously mentioned, Metro Vancouver's Cost Burden Study has confirmed that renters, especially those earning below $\$ 50,000$, have lower car ownership rates and are therefore more reliant on transit (Metro Vancouver, 2015). The study also found that as incomes decrease, 
transit ridership increases, thereby demonstrating the importance of building affordable rental housing in close proximity to the transit corridor (Metro Vancouver, 2015). However, renter households in Metro Vancouver that make less than $\$ 50,000$ spend an average of $67 \%$ of their resources on transit and housing, which represents a large cost burden for lower income households (Metro Vancouver, 2015). This cost burden is indicative of the fact that not enough affordable housing options exist along the transit corridor.

\subsection{Growth Versus Affordability: The Loss of Affordable Rental Housing in Burnaby}

Like all Metro Vancouver municipalities, Burnaby is obliged to densify around its Urban

Centres in accordance with the growth targets set out in RGS. Burnaby is home to four Town Centres: Lougheed, Brentwood, Edmonds and Metrotown, which are also identified as being Urban Centres under the RGS. More specifically, Metrotown is identified as being a Regional City Center (RCC) and Edmonds, Brentwood and Lougheed are Municipal Town Centres $(\mathrm{MTC}) .^{3}$

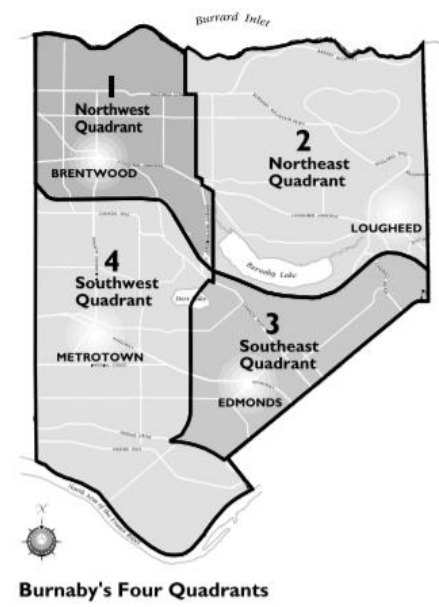

Figure 6: Burnaby's Four Town Centres (Source: City of Burnaby, 2016)

\footnotetext{
3 The RGS states that Regional City Centers are meant to serve as "regional activity hubs" and Municipal Town Centres will be local-scale activity hubs (Metro Vancouver, 2015).
} 
The policies in Burnaby's Official Community Plan (OCP) are congruent with the TOD objectives of the RGS as the Town Centres are identified as key areas to absorb "a significant portion of Burnaby's population, job growth, commercial services, and community amenities" (City of Burnaby, 2014). Furthermore, the OCP stipulates that "town centres provide for higher density forms of housing in the City's most urban settings" (City of Burnaby, 2014). The four Town Centres in Burnaby are similar in that they are within 800 meters of a rapid transit station and within 400 meters of the Frequent Transit Network as identified by TransLink (Metro Vancouver, 2015). Most importantly, they are the focal point for growth and development in each quadrant, in addition to being home to large concentrations of low-rise, multi-unit residential apartments.

The majority of the affordable purpose-built rental stock in Burnaby exists along the SkyTrain corridor. The relative affordability of these units is a function of their age and condition as much of this stock is between 30 and 60 years old and were built using federal government tax incentives (Jones, 2015). Rental housing that was built before 1980 makes up $57 \%$ of the total renter occupied dwelling units in Burnaby (Metro Vancouver, 2018). However, many of the federal operating subsidies that have helped to repair and maintain these aging apartment buildings are starting to expire without a guarantee of renewal, thereby putting the future of this housing stock in a precarious position. It is estimated that by 2023 , federal operating subsidies will have expired for 350,000 units, which represents over $50 \%$ of federally assisted units in Canada (Jones, 2015).

The value of the land that these older apartments currently occupy plays a significant role in their redevelopment potential. A property is considered be an attractive redevelopment site when the value of the land "meets or exceeds the value of its continued use as a rental property" 
(Coriolis, 2012). The value of the land along the SkyTrain corridor has surpassed the value of the rental buildings in the area, thereby making them ideal redevelopment sites. This is due to the fact that fixed-route transit makes an area more attractive for development as the limited amount of stations concentrates people and business in one area, thereby mitigating the risk for potential real estate investors (Raye, 2015). It is therefore not surprising that TOD is also linked with higher land and property values, which makes neighborhoods in existing or planned transit susceptible to gentrification (Rayle, 2015).

Furthermore, growth management policies coupled with permissive zoning for higherdensity housing provides the necessary conditions for the redevelopment potential of the area, thus increasing the value of the properties located near a transit station (Duncan 2011a; 2011b). In 2010, an amendment was made to Burnaby's zoning bylaw to update the 1997 Community Benefit Bonus Policy to allow for the creation of the 's' zoning category. The new zoning category permits an increased base and bonus density in the RM3, RM4 and RM5 zoning districts within the four Town Centres (City of Burnaby, 2011). The goal of the Supplemental Community Benefit Bonus policy is to support intensification in areas well serviced by transit, as well as provide the necessary community amenities that are supportive of the TOD planning goals of the OCP.

This policy, however, has served as the impetus for the sale and the subsequent demolition of older rental apartment buildings to build condominiums around Burnaby’s four transit-serviced Town Centres. This can be attributed to the difference between the maximum existing floorspace and maximum permitted floorspace, which serves as the strongest rationale for redevelopment of a property regardless of the age and condition (Coriolis, 2012). The blanket upzoning of the four Town Centres has increased the maximum permitted FAR for the RM3, 
RM4 and RM5 zones by 0.25, 1.6 and 2.4 respectively (Figure 7) (City of Burnaby, 2011), which has resulted in the large spike in redevelopment activity at the expense of the older rental stock.

\begin{tabular}{|l|c|c|c|c|c|}
\hline \multicolumn{2}{|c|}{ Established Base and Bonus Density } & \multicolumn{2}{c|}{$\begin{array}{c}\text { Supplementary Base and Bonus } \\
\text { Density }\end{array}$} & Total \\
\hline Zoning District & $\begin{array}{c}\text { Base } \\
\text { FAR }\end{array}$ & $\begin{array}{c}\text { Bonus } \\
\text { FAR }\end{array}$ & $\begin{array}{c}\text { Supplementary } \\
\text { Base FAR } \\
\text { (Max.) } \\
\text { "s" zoning sub- } \\
\text { category }\end{array}$ & $\begin{array}{c}\text { Supplentary } \\
\text { Bonus FAR } \\
\text { (Max.) } \\
\text { "s" zoning sub- } \\
\text { category }\end{array}$ & $\begin{array}{c}\text { Total FAR } \\
\text { "s" zoning sub- } \\
\text { category }\end{array}$ \\
\hline RM3 District & 1.1 & 0.15 & 0 & 0.25 & 1.5 \\
\hline RM4 District & 1.7 & 0.3 & 0.8 & 0.8 & 3.6 \\
\hline RM5 District & 2.2 & 0.4 & 1.2 & 1.2 & 5.0 \\
\hline
\end{tabular}

Figure 7: Supplementary Base and Bonus Density Permitted by 's' zoning (Source: City of Burnaby, 2011)

In 2017 alone, Burnaby experienced the sale of 18 apartment buildings, which was the highest of all suburban Metro Vancouver municipalities. Of the total apartment sales, 16 of them resulted in the development of high rise condominiums and many were concentrated in the Metrotown area (Goodman, 2018). The average per unit sales price increased by $66 \%$ from 2016 to 2017 (Goodman, 2018), which is indicative of the fact that favorable zoning permissions have increased the redevelopment potential of lands around the Town Centres and therefore apartment owners are selling their properties to capitalize on a market valuation that is based on the "highest and best use" (Goodman, 2018). Herein lies the root of the issue: Burnaby is aligning its policies with the TOD goals of the RGS, yet it is these policies that are perpetuating the displacement of residents who arguably are the most reliant on access to transit. This is consistent with the notion that growth management tools have been shown to disproportionately disadvantage low-income households (Addison, Zhang and Coomes, 2013). 


\subsection{EVALUATION OF CURRENT HOUSING TOOLS USED BY BURNABY}

The Local Government Act gives Burnaby the authority to implement tools and policies aimed at creating and preserving the stock of affordable housing. Burnaby uses a number different policies and initiatives to support the development both market and non-market rental housing (City of Burnaby, 2016). The goal of this section is to evaluate the perceived effectiveness of their ability to preserve affordable rental housing for low income households in the Town Centres.

As previously mentioned, the City adopted the Community Benefit Bonus (CBB) Policy in 1997 which essentially grants developers additional height and density in exchange for affordable housing and community amenities (City of Burnaby, 2016). The City is able to leverage the CBB Policy to secure on-site affordable units within a new development or alternatively, it will accept cash-in-lieu with the intention of funding off-site affordable housing (City of Burnaby, 2016). The policy stipulates that at least $20 \%$ of the cash-in-lieu funds must be assigned to a designated affordable Housing Fund, with the option of increasing the housing dedication to $100 \%$ at the discretion of Council (City of Burnaby, 2016). As of 2016, the policy has resulted in the creation of 19 units of affordable rental housing within three new developments in the Brentwood Town Centre and over $\$ 40$ million in the Housing Fund for future housing initiatives (City of Burnaby, 2016). While the policy has resulted in the inclusion of affordable units in Town Centre developments, the need far exceeds the supply. With such an urgent need for affordable units, the City could be making better use of the large amount of money in the Housing Fund to respond to this demand for housing.

Furthermore, an amendment was made to the City's zoning bylaw to update the CBB Policy to allow benefits to be allocated outside of the development receiving the density bonus, 
so long as they remain in the quadrant that contains the development project (Burnaby, 2014).

This update to the policy brings the "nexus"4 of the allocated benefits into question as any affordable units obtained are no longer required to be included in the area that is undergoing the redevelopment. This suggests the City should be more strategic in the allocation of the money in the Housing Fund. Since the majority of the money comes from new developments occurring in within the Town Centres. The City should explore innovative ways to use the fund to ensure affordable housing units remain in the areas that are undergoing redevelopment so existing tenants can remain in neighborhoods that are well-serviced by transit.

The City's Comprehensive Development (CD) District Zoning allows for greater flexibility in terms of "building setbacks, building heights and parking requirements" (City of Burnaby, 2016). The ability to amend certain zoning requirements serves as an incentive for developers to build both market and non-market rental housing since they provide bonuses that help to offset some of the costs associated with providing this type of housing (City of Burnaby, 2016). This tool has been more effective at producing more units of market rental housing than non-market rental housing. This is largely attributed to the fact that non-market housing requires additional subsidies to make the project viable, thus creating a barrier for construction of units that offer rents below market rates.

The City also supports a policy that allows certain development cost charges and development permit fees to be deferred for a period of 24 months starting from the time of final development approval for non-market housing projects (City of Burnaby, 2016). This policy acknowledges that during construction, a project does not generate any cash flow, and therefore it attempts to accommodate this by deferring a significant up-front cost (City of Burnaby, 2016).

\footnotetext{
${ }^{4}$ A clear connection between the community benefit and the nature of the development proposal.
} 
Burnaby also has a fast-track approvals policy which helps developers overcome significant administrative barriers for non-market housing projects.

Burnaby's Rental Conversion Control Policy places a moratorium on the conversion of the existing stock of purpose-built rental housing to condominiums which is aimed at preserving the older stock of rental housing in the city (City of Burnaby, 2016). However, the City does not have the legislative authority to withhold demolition permits which makes the rental conversion policy less effective at protecting the rental stock when a developer applies to redevelop the whole property.

Finally, the City's Land Leases/City Lands Program for Non-Market Housing Projects Program is used to facilitate the creation of non-market housing units. The City leases its own land "at a reduced or nominal rate" (City of Burnaby, 2016) to non-profits and other housing providers to build non-market housing. This program helps to make the provision of affordable housing more feasible by removing the cost of land. It also allows the City to retain control to ensure that the units remain affordable. While this program has added 302 units of non-market housing to the City's stock, it should be noted that none of the projects are in areas that are serviced by transit. The lack of City land holdings near transit makes this program less effective at preserving affordable options in transit-oriented locations. 


\subsection{CASE STUDIES: METRO VANCOUVER MUNICIPAL HOUSING POLICIES AND TOOLS}

The following section explores innovative strategies and tools employed by different Metro Vancouver municipalities to encourage the preservation and development of affordable rental housing. Examples from Richmond, Vancouver, New Westminster were evaluated due to their similarities to Burnaby. These municipalities are all serviced by the SkyTrain and encompass a significant amount of low-rise rental apartments that house low-income tenants. A notable precedent from Burnaby was also assessed to highlight the important role that partnerships play in non-market rental housing delivery. The intention of this section is to provide a list of best practices for the retention of affordable housing that are rooted in the Metro Vancouver policy context.

\subsection{Richmond's Inclusionary Zoning Policy and Affordable Housing Reserve Fund}

The City of Richmond is the fourth largest municipality in Metro Vancouver, with a population of 198, 309 (Statistics Canada, 2017). Richmond is characterized by a high proportion of low-income households in close proximity to the SkyTrain line and its city center is designated as a Regional City Center under the RGS (Kloepper, 2017). These underlying similarities make Richmond a suitable comparison for the City of Burnaby. The Richmond City Council adopted Richmond's first Affordable Housing Strategy in 2007 and is in the process of updating the document to accommodate changes in market conditions as well as the affordable housing needs of residents. Richmond's Affordable Housing Strategy supports a number of housing policies that enable the preservation and development of affordable rental housing. The strategy identifies low-end market rental housing as one of its key priorities, which caters to the 
housing needs of households earning between $\$ 34,000$ or less and $\$ 57,000$ or less (City of Richmond, 2016).

Richmond is the only Metro Vancouver municipality that supports a comprehensive inclusionary zoning policy. The City’s inclusionary zoning policy applies to rezoning applications for developments containing more than 80 residential units. Under the policy, the City will grant density incentives to developers in exchange for the assurance that at least $5 \%$ of the floor area will be reserved for low-end market rental units (City of Richmond, 2016). Affordability is guaranteed for these units through a Housing Agreement which secures these units in perpetuity on title (City of Richmond, 2016). While the policy stipulates a preference for the provision of affordable units in-kind, it does allow cash in-lieu for "special development circumstances" 5 (Metro Vancouver, 2012). Eligible projects for the "special development circumstance" are allowed to give their required affordable housing contribution in the form of Affordable Housing Value Transfer to the City's Affordable Housing Reserve Fund (Metro Vancouver, 2012).

The caveat placed on cash-in-lieu contributions has allowed the inclusionary zoning to be more successful in supporting the City's goals of creating mixed-income communities by enabling more low-end market rental units to be included in market developments. In 2007 Metro Vancouver projected that Richmond would need 220 low-to-moderate income units annually over ten years (City of Richmond, 2016). Since the adoption of the policy in 2007,

\footnotetext{
5 "Projects must secure rents below the rates set out in the Affordable Housing Strategy, seek financial support from other levels of government, meet the Affordable Housing Reserve Fund Policy funding priority for the provision of subsidized rental housing (i.e. low-income seniors), and be in line with the Affordable Housing Strategy proposal review and approval criteria" (City of Richmond, 2016).
} 
inclusionary zoning has successfully secured 320 low-end market rental units (City of Richmond, 2016).

Richmond also supports an Affordable Housing Reserve Fund Strategy (AHRF) which is used solely for the purpose of providing low-end market housing. All cash-in-lieu contributions obtained from the inclusionary zoning policy go directly into the AHRF which are then used for capital investments for various affordable housing initiatives such as purchasing land or units, construction financing, and joint ventures with senior levels of government, developers and other agencies (Metro Vancouver, 2012). In 2015, the City amended the AHRF strategy and accompanying bylaw to enable the increase in the contribution rates required for new developments. The impetus for the amendment was centered around the inability of the policy to achieve the affordable housing targets set out by the City and Metro Vancouver (Kloepper, 2017), as well as the projected increased demand for affordable housing stemming from the RGS. The update to the Affordable Housing Reserve Fund exemplifies a proactive response to the projections for increased housing demand.

Key lessons that can be learned from Richmond's Affordable Housing Strategy are the importance of prioritizing low end of market housing in the creation of tools and policies. While the City of Burnaby's CBB Policy is used to obtain a number of different community amenities in addition to affordable housing, Richmond's AHRF specifically targets low-to-moderate income housing needs. Richmond's inclusionary zoning policy provides a strong example of a tool that can be used to ensure affordable housing is provided in desirable neighborhoods by leveraging increased development activity.

Burnaby's CBB Policy often results in cash-in lieu which makes it difficult to ensure vulnerable tenants are able to remain in their neighborhoods following the redevelopment of 
existing buildings. The preference for on-site affordable housing provision combined with the limitations placed on cash-in-lieu contributions in Richmond's inclusionary zoning policy makes this a notable place-based strategy that serves as a worthy precedent for Burnaby to consider replicating.

\subsection{Vancouver's Rental Housing Stock Official Rate of Change Policy}

Like Burnaby, the City of Vancouver has a high proportion of older rental stock, which, coupled with increased renter demand, has catalyzed redevelopment and renovation activity in the City. The development activity has inevitably had a negative impact on existing tenants who are then left with the difficult task of finding alternative affordable housing options in a city that is characterized by low vacancy rates and increasing rents. The City of Vancouver's Rental Housing Stock Official Rate of Change Policy offers a solution to the need to both preserve and renew the existing stock of affordable rental housing at no cost to the City by leveraging the development activity occurring in desirable areas.

The policy requires that the redevelopment of apartment buildings that contain six or more rental units are replaced one-for-one in the new project (City of Vancouver, 2007). The policy is applied in zoning districts that contain a large concentration of the City's rental housing stock such as RM, FM and CD-1. The goal of the policy is to achieve a rate of change of $0 \%$ for affordable rental units to ensure that redevelopment does not come at the expense of existing residents in the affected neighborhood (Metro Vancouver, 2016).

The City uses the neighborhood planning and engagement process, urban design work, and land economic analysis to determine which areas are appropriate to accommodate the construction of new and replacement rental units (Metro Vancouver, 2016). The West End Neighborhood Plan is a successful example of how this process can enable redevelopment activity while also preserving rental housing options. The community engaged in the 
development of the West End Neighborhood Plan was asked to identify areas that should support redevelopment activity and areas that should be preserved. The areas designated as "change areas" were zoned for higher density with the intention of allowing condominiums in the redevelopment (Metro Vancouver, 2016). This was accompanied with a caveat that all demolished units be included as social units in the new development which could then be operated by a non-profit agency (Metro Vancouver, 2016). The other sites containing rental apartments that were designated as "no change areas" are subsequently protected from redevelopment activity (Metro Vancouver, 2016).

Vancouver's Rate of Change Policy serves as a strong precedent for what can be done to assist with the retention and renewal of affordable rental housing stock in areas that are experiencing significant redevelopment. The key lesson that can be learned from Vancouver's approach to rental housing preservation is that growth and development do not have to come at the expense of affordability. This case study demonstrates the importance of working with the community as well as land economics and development feasibility specialists to assess which sites should be preserved and which sites could feasibly accommodate a rental replacement policy without hindering the financial viability of the project. These elements are critical in the formulation of a strong policy framework that is capable of preserving housing affordability in rapidly developing neighborhoods.

While Burnaby does already offer a Tenant Assistance Policy, it only seeks to provide tenants with basic support to aid in the relocation process. It is evident that a tenant relocation policy must be coupled with a rental replacement policy to ensure that affected tenants are able to remain in their neighborhoods following the approval for the redevelopment or renovation of their rental building. 


\subsection{New Westminster's Secured Market Rental Housing Policy}

New Westminster is an inner-suburban municipality that is serviced by the Skytrain line, thus making it a suitable case study to analyze. Its downtown area is also designated as a Regional City Center under the RGS, therefore subjecting it to the same growth and affordability trade-offs that Burnaby is grappling with (Metro Vancouver, 2015). The City's Secured Market Rental Housing Policy, which was approved in 2013, offers a comprehensive incentive package that is geared towards encouraging the development of purpose built rental housing. One of the most notable policies is centered around transit-oriented parking regulations. This policy is aligned with the idea that renters are less likely to own vehicles than owners and therefore rental housing should be encouraged in Urban Centres and Frequent Transit Development Areas (New Westminster, 2017). This policy recognizes that parking requirements represent a significant portion of development and construction costs, therefore challenging the financial feasibility of rental projects along the transit corridor.

The Metro Vancouver 2012 Apartment Parking Study cited the cost of providing on-site underground parking as ranging from $\$ 20,000$ to $\$ 45,000$ per stall, which represents a significant cost barrier (Metro Vancouver, 2012). Furthermore, the study indicated that demand for parking tends to be less in purpose-built rental buildings as compared to owned apartment buildings (Metro Vancouver, 2016). Low renter demand for parking coupled with the high cost associated with providing this amenity suggest the relaxation of parking requirements for transit-oriented rental buildings is an obvious incentive.

The City offers relaxed parking requirements for purpose-built rental housing developments that are located within 400 meters of the Frequent Transit Network and SkyTrain stations. Developers that are building within these areas are required to provide 1 space per unit and an additional 0.1 spaces per unit for visitor parking (Figure 8) (New Westminster, 2017). 
Many developers have taken advantage of the relaxed parking requirements, which in conjunction with the City's density bonus provisions, have resulted in the addition of 1,450 new rental units to the development pipeline as of 2016 (Metro Vancouver, 2016).

\begin{tabular}{|c|c|c|c|c|c|c|c|c|c|}
\hline & \multicolumn{2}{|c|}{$\begin{array}{l}\text { Bachelor } \\
\text { suite }\end{array}$} & \multicolumn{2}{|c|}{$\begin{array}{l}\text { One Bed- } \\
\text { room }\end{array}$} & \multicolumn{2}{|c|}{ Two Bedroom } & \multicolumn{2}{|c|}{ Three or More } & \multirow{2}{*}{$\begin{array}{l}\text { Visitor } \\
\text { Min. }\end{array}$} \\
\hline & Min. & Max. & Min. & Max. & Min. & Max. & Min. & Max. & \\
\hline $\begin{array}{l}\text { Metro Vancouver: } \\
\text { Market rentals (FTN) }\end{array}$ & 0.25 & 1.00 & 0.25 & 1.00 & 0.50 & 1.00 & 1.00 & 1.50 & 0.10 \\
\hline $\begin{array}{l}\text { New Westminster Zoning } \\
\text { Bylaw Requirement }\end{array}$ & 1.00 & & 1.20 & & 1.40 & & 1.50 & & 0.20 \\
\hline $\begin{array}{l}\text { New Westminster Zoning } \\
\text { Bylaw Requirement } \\
\text { C-8 zone } \\
\text { (Mixed use sites from } \\
\text { Eighth Street to Fourth } \\
\text { Street on Columbia) }\end{array}$ & 1.0 & & 1.0 & & 1.0 & & 1.0 & & 0 \\
\hline
\end{tabular}

Figure 8: New Westminster Zoning Bylaw Requirements for Parking versus Metro Vancouver's Guidelines (Source: City of New Westminster, 2017)

While this policy is oriented toward the development of market rental housing, the key takeaways are rooted in the clear articulation of the rationale for the policy. This offers certainty to the development industry about what can be expected for rental housing development, which helps to make the process more efficient. It should be noted that additional tools, policies and partnerships will need to be layered on top of this incentive to provide below market rental housing. However, a policy that is modeled off this case study can provide significant cost savings to developers who are building housing near a transit station in Burnaby's Town Centres.

\subsection{Burnaby's Cedar Place: Public-Private Partnership}

The City of Burnaby collaborated with BC Housing and Leadingham McAllister (LedMac), on a project geared toward replacing aging affordable housing stock with 180 new, non-market housing units in the Edmonds and Southgate Village. Cedar Place is a 90-unit lowrise, non-market multifamily development that was built in 1971 and continues to be owned and operated by BC Housing (BC Housing). The City partnered with LedMac to replace all of the 
affordable units located within Cedar Place with 90 new, non-market family units in a building directly across the street from the original development, thereby allowing affected tenants to remain in their neighborhood (BC Housing). These units will continue to be owned and operated by BC Housing. The original Cedar Place site is being redeveloped to include 90 units of seniors housing on the west side of the property and the remainder of the land is being developed into market housing (BC Housing). The existing tenants in the Cedar Place development will be able to stay in their units while the new development in being constructed and then will be given the opportunity to move into the new development at a rental price that is consistent with what was previously paid (BC Housing).

The Province leveraged the land value of the Cedar Place property through the sale of the site to LedMac and the subsequent reinvestment of the profit into the new multi-family development. The most notable aspects of this project are centered around the City's involvement in the redevelopment of the Cedar Place property. Burnaby enabled the redevelopment by rezoning the property for a higher density multiple district (City of Burnaby, 2016). Furthermore, it committed an $\$ 8.5$ million contribution from its Housing Fund to help with the cost of building the seniors housing (City of Burnaby, 2016).

The Cedar Place redevelopment is an example of how partnerships between the public and private sector can be leveraged to achieve the goal of preserving and creating more affordable rental housing. A notable lesson that can be learned from this project is how funds from the City's Housing Fund can play a significant role in making non-market housing more financially viable for private developers. Land costs continue to be a significant barrier to the development of affordable housing units; therefore, municipalities and non-profit housing providers are consistently outbid by private developers who prefer to build market-rate units. By 
partnering with LedMac, the City was able to forgo the initial upfront cost of buying the land, and instead contributed funds toward building the affordable units. 


\subsection{CASE STUDIES: U.S. HOUSING POLICIES AND TOOLS}

The following section explores different policies and tools that are currently being employed in the U.S. context to encourage the preservation of affordable rental housing near transit. Precedents from Seattle, San Francisco, and Massachusetts, in addition to the widely used Low Income Housing Tax Credit were assessed and evaluated based on their applicability to Burnaby. The purpose of this section is to explore innovative tools that are not yet being employed in the Canadian context to parse out key takeaways that have the potential to be replicated in Burnaby to promote equitable transit-oriented development

\subsection{Seattle's Multifamily Property Tax Exemption Program}

Property taxes represent a significant cost barrier that erodes the profitability of investing in rental housing. In Burnaby, there is currently no official incentive program in place to offset the cost of property taxes. On the other hand, Seattle is a city that is experiencing a similar challenge in terms of addressing the demand for rental housing options as nearly $52 \%$ of households are renters (Bula, 2016). Similar to Burnaby, the city offers density bonus incentives, reduced development charges and parking requirements to encourage the development of purpose-built rental housing (Bula, 2016).

However, Seattle differs from Burnaby in that it offers developers a property tax exemption on buildings that incorporate affordable rental units (Bula, 2016). As of 2016, the Multifamily Property Tax Exemption (MFTE) Program has successfully added approximately 7500 units of affordable rental units to the city's housing stock (Trumm, 2017). The notable difference between this program and other tax exemption programs is that Seattle's MFTE program goes beyond the simply requiring the units to be rental; eligibility for a tax exemption is contingent on rents being restricted to affordable levels. The program bolsters the idea that a 
return to a more equitable tax treatment for rental properties serves as a catalyst in the construction of this type of housing tenure.

The impetus for Seattle's Multifamily Property Tax Exemption program is to encourage the incorporation of affordable rental units into market-rate buildings so that moderate income households can live in areas of the city that would otherwise be inaccessible (Hoffman, 2011). According to Washington State's Growth Management Act, municipalities that have identified urban centers with a shortage of affordable housing options are eligible to implement the MFTE Program (City of Seattle Office of Housing, 2017).

The program provides owners and developers of multifamily rental and ownership residential properties with a 12-year property tax exemption on the building in exchange for setting aside a minimum of $20 \%$ of the units as affordable rentals (City of Seattle Office of Housing, 2017). The tax exemption is available for residential improvements for properties that are entirely rental tenure as long as a minimum of 20 percent of the units are rented at below market rates (City of Seattle Office of Housing, 2017). The affordability requirements are determined by the type of unit; the rent for studio units must be either at or below $65 \%$ of the area median income (AMI), 75\% of the AMI for 1-bedroom units and $85 \%$ of the AMI for 2bedroom and larger units (Trumm, 2017). In the case of properties that include ownership units, the tax exemption will apply to these units as long as the building meets the $20 \%$ affordable unit requirement (City of Seattle Office of Housing, 2017).

Between 1998 and 2015, rental housing projects have represented a greater share of overall MTFE applications when compared to for-sale projects (City of Seattle, 2017). This demonstrates the success the program has had in incentivizing the construction of more 
affordable purpose-built rental housing in desirable, high growth areas of the city (Hoffman, 2017).

While Seattle has successfully used property tax exemptions to facilitate the development of affordable units in high growth areas, it is important to consider who ultimately bears the cost of the program. Inevitably, the burden of property tax gets redistributed to those who are not participating in the MFTE program. The assessed value of the residential property improvements for proposed projects is calculated only during the initial years of construction. There is no secondary assessment that occurs after the completion of the project, and therefore the increased value of the property is not included in the tax exemption calculation (City of Seattle Office of Housing, 2017).

In many cases, the increase in tax burden associated with the MFTE participating projects is then passed onto the non-exempt projects. However, the Seattle Office of Housing has determined that the shift in tax burden to non-exempt properties is relatively minimal and instead, the decrease in property tax money is absorbed by the city as a loss in revenue. The Seattle $\mathrm{OH}$ estimated that in 2015, the MFTE tax breaks resulted in a \$6.6 million loss in potential revenues for the city and shifted $\$ 5.4$ million from participating developers to the nonparticipating taxpayers (Trumm, 2017). While the program contributes to a decrease in tax revenue for the city, it can be argued that the creation of much needed affordable rental housing offsets this loss. Instead of relying on municipal revenue raising tools to fund this public benefit, Seattle can indirectly finance affordable housing by redirecting the both the cost of building the participating MFTE project and subsidizing the units to the private developer.

Seattle and Burnaby have very similar housing climates, which makes Seattle's MFTE Program a suitable case study to explore when considering strategies that could be emulated to 
preserve and construct affordable rental housing in Burnaby. Seattle's MFTE Program targets high growth areas in accordance with the planning objectives outlined in Washington's Growth Management Act. Similarly, Burnaby is required to densify around transit hubs and Urban Centres under the direction of the RGS (Metro Vancouver, 2015) and therefore it could emulate Seattle by targeting the areas that have been designated for growth by regional policy. The area along the SkyTrain corridor is currently experiencing the greatest amount of redevelopment and therefore it is an appropriate place to accommodate a tax exemption policy.

Section 226 of British Columbia's Community Charter provides the legislative authority to municipalities to exempt certain properties from property taxes. However, the use of this authority is contingent on the creation of a revitalization tax exemption program bylaw which must be inclusive of clearly defined objectives for the program, a description of how the program will accomplish these objectives, a description of the types of properties that will be eligible for the exemption, and the amount and maximum duration of the exemption, which cannot exceed ten years (BC Ministry of Community Services, 2008). There are many examples of different revitalization objectives that are eligible for property tax exemption under the Community Charter. The construction and preservation of purpose-built rental housing falls under the social revitalization objective. The City would therefore be able to enter into an agreement with the private sector to encourage the construction affordable rental housing in exchange for a property tax exemption,

\subsection{Massachusetts Smart Growth Zoning Overlay District Act}

Massachusetts enacted the Smart Growth Zoning and Housing Production Act (Chapter 40R) in 2004 with the goal of encouraging a compact residential and mixed-use development in "smart growth" locations. The state government provides a financial incentive in the form of a direct cash payment to cities and towns who adopt the "smart growth overlay district" into their 
zoning bylaw, which essentially allows high density development as-of-right (Raitt and Verrilli, 2009). The rationale for the policy was rooted in the idea that development costs would be reduced through the creation of districts that were pre-zoned for high density development (Raitt and Verrilli, 2009). The purpose of the overlay district is to allow for special zoning permissions that operate on top of existing zoning in areas that meet the eligibility requirements outlined by the state government. The 40R overlay districts can only be created in areas that are in close proximity to transit, have concentrated development or are deemed to be "highly suitable" (Raitt and Verrilli, 2009).

Municipalities must include an affordability requirement in their bylaw to receive approval. The state requires that at least $20 \%$ of the housing units developed within the smart growth overlay district must be set aside for households that earn below $80 \%$ of the area medium income for a minimum of 30 years ((Raitt and Verrilli, 2009). Furthermore, the bylaw must stipulate that each individual project with 13 or more units meets the $20 \%$ affordability requirement ((Raitt and Verrilli, 2009). Out of the 27 communities that have adopted the smart growth overlay district zoning, approximately half have required a $25 \%$ affordable set aside rate for rental projects. Of these communities, four have lowered the affordable requirement to $20 \%$ if the rents charged for the units are targeted toward households that earn below $50 \%$ of the area medium income (Raitt and Verrilli, 2009).

The smart growth overlay district is an interesting case study because it incorporates an affordability requirement into the transit-oriented development model, thus making it a suitable model for replication in Burnaby. While the long-term implications of the policy are still unknown, the successful creation of 27 overlay districts demonstrates that it is viewed as an attractive policy tool to encourage TOD and affordability goals. 
Parallels can be drawn between the smart growth goals of the 40R statute and the transitoriented development goals of the RGS as both policies are designed to direct growth and development to existing built up areas that are well serviced by high order transit. The most notable takeaway from this case study is the role that the state government plays in the entrenchment of an affordability provision within the statutory requirements for the overlay districts. This suggests that the Metro Vancouver Regional Government could be more prescriptive about the type of growth that should be occurring around Urban Centres. A regionwide affordability requirement for up-zonings that occur within high growth areas would add more certainty to the development approvals process while increasing consistency across Metro Vancouver. It will also ensure that affordability is linked with proximity to transit.

The key challenges will be centered around ensuring that the additional cost associated with a $20 \%$ affordability requirement will not deter development from occurring as well as ensuring the cost is not passed onto market rate units. It should be noted that many of the income-restricted projects that were built under the smart growth zoning overlay have relied on state or federal subsidy programs (Raitt and Verrilli, 2009). This suggests that government support is inevitably needed to mitigate against market failure. The timing is opportune given the provincial government's recent commitment to invest in more affordable rental housing. This suggest the province could play a role by giving participating municipalities additional funds to support this type of policy.

\subsection{San Francisco Bay Area Transit Oriented Affordable Housing Fund}

San Francisco is a city that shares a similar physical geography to Metro Vancouver which makes it a suitable comparison. Its coastal orientation coupled with its proximity to a significant mountain range presents the same desirable characteristics that induce demand, while simultaneously presenting physical barriers that constrain supply. Furthermore, the economic 
prosperity of the City has inevitably facilitated an upward trend in real estate prices, thus jeopardizing the ability of the City to preserve affordability. Approximately half of households in the Bay Area pay more than 30\% of their income on housing costs, with households making between $\$ 20,000$ and $\$ 50,000$ per year spending 63\% income on housing (Hyslop, 2015).

Since 2011, U.S. federal funding for housing has been in decline and therefore housing investment by the California state government has been marginal (Hyslop, 2015). Given the lack of upper government involvement in housing, a coalition of Bay Area non-profits known as the Great Communities Collaborative (GCC) formed a partnership with the Metropolitan Transportation Commission (MTC) and the Association of Bay Area Governments to jointly finance the $\$ 50$ million Transit Oriented Affordable Housing (TOAH) fund (Hyslop, 2015). The TOAH is an example of a transit-oriented Structured Fund, which is a tool that has been widely used in the United States to preserve affordable housing in areas that are serviced by transit. The goal of the TOAH fund is to invest in areas that are planned for high-density, compact development and are well serviced by high order public transit.

It is important to note that the successful creation of the TOAH was predicated on the initial $\$ 10$ million investment that was made by the MTC and its commitment to absorb any of the Fund's losses. The presence of a public sector actor as the provider of the equity for the fund reaffirmed the political and financial commitment to creating equitable transit-oriented developments, thus providing a strong incentive for interested investors to commit to the fund (Seifel Consulting, 2013). Furthermore, the MTC required at 3:1 leverage ratio which allowed the initial investment of $\$ 10$ million to by another $\$ 40$ million (Seifel Consulting, 2013). The patient start-up capital provided by the GCC was necessary to ensure the Fund could overcome the volatility of the initial stages of implementation. Additionally, $80 \%$ of the initial capital costs 
were supplied by big banks (Bay Area TOAH Fund). Due to the contributions from the identified non-profit, private and pubic sources, the fund has grown to $\$ 87.5$ million as of 2015 (BC NonProfit Housing Association, 2017).

The impetus for the fund was rooted in the acknowledgement that land acquisition and construction costs serve as a significant barrier to the development of affordable housing in desirable locations. The TOAH Fund offers acquisition loan, predevelopment loans, construction bridge loans, construction-to-mini-permanent loans as well as leveraged loans (Seifel Consulting, 2013). Eligible entities can borrow up to $\$ 750,000$ to over predevelopment costs and up to $\$ 7.5$ million for other loan needs (Seifel Consulting, 2013). Repayment terms are dependent on the type of loan that is given but typically requires interest only payments or a combination of interest and principal (Seifel Consulting, 2013). Upon maturity, the entire balance of the loan is required to be repaid. The fund operates as a Limited Liability Corporation (LLC) which protects the members from any liabilities or debts the fund may incur due to issues with repayment from the borrowers (Seifel Consulting, 2013).

Access to the Fund is contingent on at least $75 \%$ of all units being affordable for households with incomes equal to or below $80 \%$ of the area medium income (AMI) (Seifel Consulting, 2013). In the case of multifamily rental projects, a minimum of $20 \%$ of units must be accessible for households with incomes equal to or less than $50 \%$ of the AMI. The preference for use of the Fund is for rental projects that target lower income households.

The Bay Area's Transit Oriented Affordable Housing Fund (TOAH) is a successful example of a collaborative approach to affordable transit-oriented development. The formation of a transit-oriented structure fund is something that could be replicated in Burnaby to incentivize the creation of affordable housing along the transit corridor. The key lesson to be 
learned from the TOAH is the importance of establishing a shared vision and relationships built on trust amongst key stakeholders. Additionally, the case study demonstrates the need for patient capital from an investor with a social mandate.

\subsection{U.S. Low Income Housing Tax Credit}

Since 1986, the federal government's Low-Income Housing Tax Credit Program (LIHTC) has been a significant funding tool used in the U.S. to facilitate the creation of affordable housing. The U.S. Department of Treasury issues tax credits to the state governments who then create qualified allocation plans (QAPs), which describe the selection criteria for interested developers (Keightley, 2013). Developers then apply for the tax credits, those who meet the eligibility criteria are selected and awarded the credits. The affordable housing feasibility piece comes from the transaction that occurs between investors, who buy the tax credit, and the developer who then uses the equity from the sale to lower the debt to loan ratio for a project (Keightley, 2013). The reduced debt makes the prospect of building housing units that charge below market rents much more viable for the developer.

In the application for the tax credit, the developer must include which of the two "set aside" conditions they are committing to. If the developer selects the $20 \%$ at $50 \%$ set aside option, they are committing to renting $20 \%$ of the affordable rental units to residents who have a household income of $50 \%$ or less of the area median gross income (Keightley, 2013). The $40 \%$ at $60 \%$ set aside option results in the developer renting $40 \%$ of the below market units at $60 \%$ or less of the AMI (Keightley, 2013). The number of tax credits awarded to the developer is contingent on the percentage of low-income units in the property, therefore creating an incentive to include more units of affordable housing.

The LIHTC is also used as a tool to both preserve and construct affordable housing in areas that are serviced by transit. Twenty-eight state governments either include proximity to 
transit as a requirement for eligibility for the tax credit or give priority to transit-oriented projects (Reconnecting America, 2006). By offering more competitive scoring to affordable housing projects that are transit accessible, there is more incentive to build these types of projects.

The LIHTC has not yet been employed in the Canadian context, however parallels can be drawn between the program and the rental housing tax incentives that were previously offered by the federal government. The success of the LIHTC bolsters the idea that a favorable tax regime coupled with prescriptive requirements for qualifying projects can help to facilitate the creation of equitable transit-oriented development. 


\subsection{INTERVIEW FINDINGS}

This next section offers a synthesis of the key findings obtained from interviews with both the public and private sector on the challenges and opportunities associated with building affordable rental housing along the transit corridor in Burnaby. It was important to conduct primary research with professionals who understand the planning and development context in Burnaby in order to gain insight into the tools and policies that could feasibly be implemented.

\subsection{Private Sector}

Since the private sector is the primary builder of housing in Burnaby, it was important gain the perspectives of developers on equitable transit-oriented development. Only developers working on development projects within the Town Centres were selected for the interview process to ensure the information obtained was aligned with the objectives of this research. The interview questions were open-ended to allow for an organic discussion to occur.

\section{Burnaby's Planning and Development Process}

One developer stated they felt positive about the planning and development process in Burnaby, it was praised as being transparent and proactive. It was noted that the City is very prescriptive about where density should occur, as it is clearly articulated in their policies. The consistency of the land use planning framework in Burnaby allows both residents and developers to be on the same page in terms of how and where growth and development should occur city. The formulaic nature of the CBB Policy in Burnaby was cited as being a significant strength as it provides certainty about what a developer is expected to provide in exchange for more height and density. Since the same formula is applied to every development project, developers can create their proforma with relative certainty in advance of interactions with the city. 


\section{$\underline{\text { Lead Time Required for Policy Implementation }}$}

A key takeaway from the interviewing process was the importance of lead time when it comes to policy implementation. Developers operate in a market economy and therefore economic conditions must be taken into consideration when creating policy. Inherent in the industry is the reality that a certain profit must be made from development projects. Developers make assumptions about future market conditions to determine the expected revenues and costs for a project. These assumptions, coupled with their own profit margins determine how much they can pay for land. An affordable housing requirement will add to the development and operating costs in a proforma, thereby reducing the return that can be made from a project. This highlights why significant lead time is required in advance of implementing an affordable housing policy to ensure developers have enough time to adjust their proformas to reflect any additional costs they will inevitably incur.

\section{Parking Reductions as an Incentive}

Another key takeaway was the cost barrier that parking requirements provide for projects in close proximity to transit. Even though many municipalities offer parking reductions, this was still cited as being too high. The argument is that projects are being built in locations that are preferred by policymakers, yet municipal incentives have not followed the same logic.

Furthermore, it was noted that these costs ultimately get passed down to the end user, which is an issue in transit-oriented areas that are characterized by less car dependence. This is because residents who do not own a car are essentially subsidizing the unit of a resident who owns a car.

\section{Perceived Risks of Rental Projects}

The risk associated with building rental projects was articulated as being a major barrier to the construction of purpose-built rentals. Apartments buildings must generate at least a 3.5\% 
return, however the caps on rent increases inhibit the ability of the apartment building owner to cover their costs and generate their desired return. Condominium rental apartments were seen as a more viable way to create rental stock as no return on investment is required, instead the owner only needs to generate enough rent to cover their mortgage.

While some developers are building purpose-built rental housing, prevailing market conditions were seen as a significant barrier to reducing the rent to more affordable levels. In order to create affordable units, developers are forced to pass this cost onto other residents in the building. Partnerships with the public sector were viewed as a viable way to create units that reach deeper levels of affordability.

\subsection{Public Sector}

Correspondence with City of Burnaby Planning staff was used to garner insight into the practical realities of affordable rental housing preservation and construction in the city. Burnaby staff acknowledged the role that non-market rental housing plays in creating a "more inclusive and socially diverse community" by providing workforce housing as well as affordable options for BCIT and SFU students.

\section{Barriers to Rental Housing Preservation}

Lack of legal authority was cited as a significant barrier to the City's ability to preserve the aging affordable rental housing stock. More specifically, staff indicated that the inability to withhold a demolition permit that adheres both the BC Building Act and the BC Building Code weakens the City's capacity to protect rental housing. The City noted that enhanced legal tools, such as the ability to refuse demolition permits coupled with the ability to zone for rental housing would allow the City to be more successful in both preserving and constructing affordable rental housing. Efforts have been made to lobby the provincial government for these tools, however the requests have been denied. 
The City divides affordable rental housing into three main categories: non-market rental housing, purpose-built market rental housing and secondary market rental housing. Non-market rentals refer to the housing stock that is owned and operated by non-profit entities or senior levels of government. Affordable purpose-built market rental housing refers to the existing stock of low-rise apartments that were built using federal tax subsidies. In both cases, lack of provincial and federal funding over the past twenty years was cited as a significant barrier to both preserving and constructing rental housing that offers rents below the market price. Given the substantial set of tools that are afforded to upper-level governments, the City identified affordable rental housing provision as being the primary responsibility of federal and provincial governments, with local municipalities serving a support role.

\section{Re-engagement of the Federal Government}

The City identified the re-engagement of provincial and federal governments in housing provision as a promising opportunity for the reinvestment in non-market rental housing. This has resulted in the addition of new units of affordable rental housing to Burnaby's rental stock. City staff noted that over 700 units of non-market housing were in the development pipeline, either in the rezoning phase or under construction because of upper-level assistance. In light of the recent announcement of the National Housing Strategy, Burnaby staff have lobbied for a restoration of federal tax incentives that enable the viability of affordable rental housing construction as well as funding that is specifically targeted toward non-market housing.

\section{Perspectives on a 1:1 Replacement Policy}

Burnaby does not currently have a policy that requires a 1:1 replacement of demolished market rental units in new developments. Instead, the use of incentives to encourage purposebuilt rental housing in new development is considered by the City on a case-by-case basis. The 
main concerns surrounding the implementation of this policy are centered around the incentives that will be required to make rental replacement economically viable for developers. The City has acknowledged that increased density or financial incentives would need to accompany a requirement to replace market rental units in a new development. This means that public money would essentially be subsidizing private developments, which Burnaby feels is a role for senior levels of government.

Concerns over the possible capitalization of additional development costs associated with market rentals into the market price of ownership units were also identified by the City. The rationale for allowing the market to build the housing without a replacement requirement is based on the fact that many of the condominium units that are built in new developments get rented out and are added to the secondary rental market stock. It was determined by the City that this approach has resulted in more units being added to the rental stock when compared with a replacement policy. It should be noted that these units rent for significantly higher than what was charged for the rental unit in the original low, rise rental building.

The City acknowledged that the real value associated with a rental replacement policy occurs when it is used to construct new units of non-market housing. The City has engaged in partnerships with developers, non-profit actors and the province to replace aging rental stock with new non-market housing units as part of the site redevelopment. While the rental replacement process is not a formal policy, it should be noted that these partnerships have been successful in allowing residents of the existing rental buildings to remain in their neighborhoods. 


\subsection{SUMMARY OF FINDINGS}

\begin{tabular}{|c|c|c|c|c|}
\hline $\begin{array}{l}\text { Metro } \\
\text { Vancouver } \\
\text { Case Studies }\end{array}$ & Objective & $\begin{array}{l}\text { Actors } \\
\text { Involved }\end{array}$ & $\begin{array}{l}\text { How Does It Preserve } \\
\text { Affordability? }\end{array}$ & $\begin{array}{l}\text { Barriers to Application } \\
\text { in Burnaby }\end{array}$ \\
\hline $\begin{array}{l}\text { Richmond's } \\
\text { Inclusionary } \\
\text { Zoning Policy } \\
\text { and Affordable } \\
\text { Housing } \\
\text { Reserve Fund }\end{array}$ & $\begin{array}{l}\text {-Facilitate the } \\
\text { inclusion of } \\
\text { low-end } \\
\text { market rental } \\
\text { housing in new } \\
\text { developments }\end{array}$ & $\begin{array}{l}\text {-Municipal } \\
\text { Government } \\
\text {-Private } \\
\text { Sector }\end{array}$ & $\begin{array}{l}\text {-At least } 5 \% \text { of the floor area in } \\
\text { the new development must be } \\
\text { reserved for low-end market } \\
\text { rentals } \\
\text {-Funds in the AHRF are used } \\
\text { specifically for capital } \\
\text { investments for new affordable } \\
\text { housing initiatives }\end{array}$ & $\begin{array}{l}\text {-Burnaby's aversion to } \\
\text { providing additional } \\
\text { density allocations to } \\
\text { support market rental } \\
\text { housing provision in for- } \\
\text { profit developments as } \\
\text { their might be local } \\
\text { community impacts. }\end{array}$ \\
\hline $\begin{array}{l}\text { Vancouver's } \\
\text { Rental Housing } \\
\text { Stock Official } \\
\text { Rate of Change } \\
\text { Policy }\end{array}$ & $\begin{array}{l}\text {-To retain the } \\
\text { stock of } \\
\text { affordable } \\
\text { rental housing } \\
\text { and prevent } \\
\text { displacement }\end{array}$ & $\begin{array}{l}\text {-Municipal } \\
\text { Government } \\
\text {-Private } \\
\text { Sector } \\
\text {-Non-Profit } \\
\text { Sector }\end{array}$ & $\begin{array}{l}\text {-Ensures the existing affordable } \\
\text { rental stock is replaced one for } \\
\text { one in a new development } \\
\text {-Non-profit sector will take over } \\
\text { the operation of non-market } \\
\text { units }\end{array}$ & $\begin{array}{l}\text {-Burnaby is not supportive } \\
\text { of using public funds and } \\
\text { density allocations to } \\
\text { support market rental } \\
\text { replacement in for-profit } \\
\text { developments }\end{array}$ \\
\hline $\begin{array}{l}\text { New } \\
\text { Westminster's } \\
\text { Secured Market } \\
\text { Rental Housing } \\
\text { Policy }\end{array}$ & $\begin{array}{l}\text {-Incentivize the } \\
\text { construction of } \\
\text { purpose-built } \\
\text { rental units in } \\
\text { areas serviced } \\
\text { by transit } \\
\text {-Streamline the } \\
\text { development } \\
\text { process }\end{array}$ & $\begin{array}{l}\text {-Municipal } \\
\text { Government } \\
\text {-Private } \\
\text { Sector }\end{array}$ & $\begin{array}{l}\text {-Reduces a significant } \\
\text { development cost, thereby } \\
\text { making rental units more viable. }\end{array}$ & $\begin{array}{l}\text {-No assessed barriers as } \\
\text { the City already supports } \\
\text { this incentive on a case- } \\
\text { by-case basis }\end{array}$ \\
\hline $\begin{array}{l}\text { Burnaby’s } \\
\text { Cedar Place: } \\
\text { Public-Private } \\
\text { Partnership }\end{array}$ & $\begin{array}{l}\text {-Preserve } \\
\text { existing non- } \\
\text { market units } \\
\text { while also } \\
\text { adding new } \\
\text { affordable } \\
\text { rental units to } \\
\text { the stock }\end{array}$ & $\begin{array}{l}\text {-Municipal } \\
\text { Government } \\
\text {-Private } \\
\text { Sector } \\
\text {-Provincial } \\
\text { Government }\end{array}$ & $\begin{array}{l}\text {-Province retains control over } \\
\text { units and therefore ensures they } \\
\text { are affordable }\end{array}$ & $\begin{array}{l}\text {-Provincial land is } \\
\text { required } \\
\text {-Contingent on the will of } \\
\text { the private sector }\end{array}$ \\
\hline
\end{tabular}




\begin{tabular}{|c|c|c|c|c|}
\hline $\begin{array}{l}\text { U.S Case } \\
\text { Studies }\end{array}$ & Objective & $\begin{array}{l}\text { Actors } \\
\text { Involved }\end{array}$ & $\begin{array}{l}\text { How does it Preserve } \\
\text { Affordability? }\end{array}$ & $\begin{array}{l}\text { Barriers to Application } \\
\text { in Burnaby }\end{array}$ \\
\hline $\begin{array}{l}\text { Seattle's } \\
\text { Multifamily } \\
\text { Property Tax } \\
\text { Exemption } \\
\text { Program }\end{array}$ & $\begin{array}{l}\text {-Facilitate the } \\
\text { development } \\
\text { of affordable } \\
\text { rental units in } \\
\text { high growth } \\
\text { areas through } \\
\text { tax exemptions }\end{array}$ & $\begin{array}{l}\text {-State } \\
\text { Government } \\
\text {-Municipal } \\
\text { Government } \\
\text {-Private } \\
\text { Sector }\end{array}$ & $\begin{array}{l}\text {-A 12-year property tax } \\
\text { exemption is provided to } \\
\text { developers and owners of } \\
\text { multi-family residential } \\
\text { properties that include a } \\
\text { minimum of } 20 \% \text { of units with } \\
\text { below market rents }\end{array}$ & $\begin{array}{l}\text {-Requires a revitalization } \\
\text { bylaw to be established } \\
\text {-Affordability } \\
\text { requirements will need to } \\
\text { be determined }\end{array}$ \\
\hline $\begin{array}{l}\text { Massachusetts } \\
\text { Smart Growth } \\
\text { Zoning Overlay } \\
\text { District Act }\end{array}$ & $\begin{array}{l}\text {-To ensure } \\
\text { affordable } \\
\text { rental units are } \\
\text { included in } \\
\text { smart growth } \\
\text { areas }\end{array}$ & $\begin{array}{l}\text {-State } \\
\text { Government } \\
\text {-Municipal } \\
\text { Governments }\end{array}$ & $\begin{array}{l}\text {-Developers that are developing } \\
\text { in areas pre-zoned for high- } \\
\text { density development must } \\
\text { include a minimum of } 20 \% \text { of } \\
\text { units at below } 80 \% \text { of the area } \\
\text { medium income. }\end{array}$ & $\begin{array}{l}\text {-Requires buy-in from the } \\
\text { provincial government } \\
\text {-Requires financial } \\
\text { assistance from senior } \\
\text { levels of } \\
\text { government }\end{array}$ \\
\hline $\begin{array}{l}\text { San Francisco } \\
\text { Bay Area } \\
\text { Transit Oriented } \\
\text { Affordable } \\
\text { Housing Fund }\end{array}$ & $\begin{array}{l}\text {-Reduce } \\
\text { development } \\
\text { costs to } \\
\text { incentivize the } \\
\text { construction of } \\
\text { affordable } \\
\text { rental units in } \\
\text { close } \\
\text { proximity to } \\
\text { transit }\end{array}$ & $\begin{array}{l}\text {-Regional } \\
\text { Government } \\
\text {-Transit } \\
\text { Authority } \\
\text {-Non-Profit } \\
\text { Sector } \\
\text {-Financial } \\
\text { Institutions }\end{array}$ & $\begin{array}{l}\text {-Loans are provided for } \\
\text { residential development } \\
\text { projects that include a } \\
\text { minimum of } 20 \% \text { of units for } \\
\text { households that have incomes } \\
\text { at } 50 \% \text { or less of the AMI, or } \\
75 \% \text { of units for households } \\
\text { with an income at } 80 \% \text { of the } \\
\text { AMI }\end{array}$ & $\begin{array}{l}\text {-Requires patient funding } \\
\text {-Collaboration between } \\
\text { key stakeholders is } \\
\text { required } \\
\text {-TransLink is currently not } \\
\text { involved in housing } \\
\text { provision }\end{array}$ \\
\hline $\begin{array}{l}\text { U.S. Low } \\
\text { Income Housing } \\
\text { Tax Credit }\end{array}$ & $\begin{array}{l}\text {-Preserve and } \\
\text { construct } \\
\text { affordable } \\
\text { housing } \\
\text { desirable areas }\end{array}$ & $\begin{array}{l}\text {-Federal } \\
\text { Government }\end{array}$ & $\begin{array}{l}\text {-Projects that set aside units for } \\
\text { affordable housing are eligible } \\
\text { for tax credits which can be } \\
\text { sold to investors to help offset } \\
\text { development costs }\end{array}$ & $\begin{array}{l}\text {-Requires a renewal of } \\
\text { federal tax incentives } \\
\text {-Takes time to set up the } \\
\text { eligibility requirements }\end{array}$ \\
\hline
\end{tabular}




\subsection{DISCUSSION AND RECOMMENDATIONS}

A key takeaway from this research is that there is no silver bullet for encouraging the preservation of affordable rental housing along the transit corridor in Burnaby. This highly complex problem requires the combination of a number of innovative policy responses as well as creative partnerships with key housing stakeholders as well as upper levels of government. The following is a set of six recommendations that are rooted in the key findings from the review of literature and precedent research, as well as stakeholder interviews.

\section{Recommendation One: Develop an Affordable Housing Strategy that Targets the Housing} Needs of Very Low and Low-Income Households

In order the achieve the goal of "providing diverse and affordable housing choices" that is outlined in the RGS, the regional government advocates for the joint creation of Housing Action Plans with the local municipalities (Metro Vancouver, 2015). The City of Burnaby has noted that it will be developing a Housing Strategy in conjunction with its OCP review, therefore the time is opportune to evaluate different policies and tools that could be used to respond to the need for affordable rental housing along the transit corridor.

Richmond's prioritization of low end market rentals its housing strategy has been identified as a best practice, therefore it is recommended that Burnaby's strategy include policies that prioritize very low and low-income households as the housing need far exceeds the supply for these groups. This will ensure the strategies that are developed are capable of addressing the unique needs of the target demographic. As previously noted, households that earn below $\$ 50,000$ per year are the most reliant on access to transit, therefore the housing strategy should include an affordability definition that acknowledges transit as part of monthly housing costs. 


\section{Recommendation Two: Implement a Transit-Oriented Inclusionary Zoning Policy}

The implementation of an inclusionary zoning policy that requires affordable units to be included in new developments along the transit corridor is a policy response that would address the connection between transit accessibility and housing affordability that has been identified by this research.

The regional government should play a role in facilitating the creation of an equitable transit-oriented development policy framework under which all municipalities in the region would be required to adhere to. The RGS provides growth targets for dwelling units and employment in each type of Urban Centre, therefore it is recommended that these targets include affordable dwelling unit targets. This will ensure the growth and development prescribed in the RGS is inclusive of affordable options. The regional government should collaborate with municipal governments to create their own respective inclusionary zoning requirements as this will ensure the policy accommodates the unique needs of each jurisdiction. The regional government should also clearly articulate what the buffer should be for the transit-oriented inclusionary zoning policy as it was noted from correspondence with the private sector that developers prefer consistent and transparent policy frameworks.

Richmond's inclusionary zoning policy offers a strong example of how increased density allocations can be used to incentivize the inclusion low end market units in market rate developments without requiring further assistance from the City to manage or operate the units. Burnaby already offers increased density to new developments in exchange for community amenities through its CBB Policy, therefore it should amend the policy framework to require a minimum of $20 \%$ affordable rental units be included in all new developments. Since affordable 
rental housing has been identified as a significant need, the City should prioritize this benefit in its CBB policy.

Furthermore, the use of the money in the Housing Fund could help to subsidize the development of these units at below market rates. Since the primary source of the funds is cashin-lieu contributions from for-profit developments located in the Town Centres, the City could use the large amount of reserve funds to aid in increasing the viability of providing affordable rental units in new, for-profit developments.

The prioritization of low income groups as the target demographic for the inclusionary zoning would make this policy tool more effective at mitigating the impacts of gentrification, as demonstrated by Richmond. Burnaby could leverage its tenant relocation program to ensure displaced residents are given priority for the affordable units in the new development. Furthermore, the policy should encourage the provision of in-kind affordable units rather than default to cash-in lieu to provide more opportunity for affected residents to stay in their neighborhood following the redevelopment.

\section{Recommendation Three: Facilitate a Collaborative Policy Making Process}

A notable takeaway from Vancouver's Official Rate of Change Policy was the inclusion of community members as well as land development consultants in the policy making process. A key concern expressed by the City of Burnaby was the negative impact that increased density allocations may pose to the local community. By including the community in the determination of growth and preservation areas, the City could mitigate the negativity surrounding increased density or uses of public funds to subsidize for-profit developments. Furthermore, a real estate land economics development study could help to make mixed-income projects feasible for developers. 


\section{Recommendation Four: Continue to Build Strong Relationships with Key Housing $\underline{\text { Stakeholders }}$}

The Cedar Place case study demonstrates the importance of leveraging partnerships with both the province and the private development sector to preserve non-market rental units as well as provide new units of affordable housing in new developments. Interview responses from the City confirmed that this case study is a successful model that should be replicated.

It is clear there is developer interest in participating in affordable housing development, therefore the City should continue to build mutually beneficial relationships with the private sector that are based on a shared understanding of the importance of providing affordable housing options. Furthermore, as articulated through correspondence with the private sector, the strength of city-developer relations is predicated on the inclusion of substantial lead time before new policies are implemented to ensure the private sector has time to adjust.

In light of the provincial government's promise to invest in more affordable rental housing, both in-kind and through funding agreements, it is recommended the City explore opportunities for more partnerships with upper-levels of government. In terms of provincial land holdings, it is recommended the City liaise with the province to determine if there are any appropriate sites along the transit corridor that could be used to jointly develop affordable rental housing. Partnerships with senior levels of government are necessary to help the City respond to the demand for more non-market rental housing that caters to the needs of very low-income households.

It should also be noted that the non-profit sector plays a significant role in the provision of affordable rental housing options, therefore the City should also continue to leverage opportunities for partnerships with this key housing stakeholder. 


\section{Recommendation Five: Create a Revitalization Tax Exemption Bylaw for Affordable $\underline{\text { Rental Housing }}$}

This research has identified property tax reduction as a tool to incentivize the inclusion of affordable rental housing units in new developments. Through the creation of a social revitalization tax exemption program, Burnaby could enter into agreements with developers which, under Section 905 of the Local Government Act, would require them to construct and preserve affordable rental housing in exchange for property tax breaks (BC Ministry of Community Services, 2008).

A rental specific tax exemption program that offers a property tax reduction to developers that set aside a certain number of units as affordable rental housing could be used in conjunction with the other tools the City of Burnaby has to encourage the private sector involvement in rental housing provision. The policy should target low income households; therefore, rents should be restricted to between $50 \%$ and $80 \%$ of the regional median income.

Furthermore, as part of the 2018 Budget, the provincial government has agreed to match the municipal property tax exemptions for purpose-built rental housing that can be provided through a municipal revitalization agreement (Province of British Columbia, 2018). This commitment from the province provides an additional incentive to construct affordable rental housing.

\section{Recommendation Six: Coordination of Relevant Stakeholders to Discuss the Potential of a} Transit Oriented Structured Fund

Transit Oriented Structure Funds have proven to be a key policy tool used in the U.S. to encourage the inclusion of affordable rental housing within transit-oriented developments. As noted in the case study review, strong partnerships as well as seed funding from a key publicsector actor played a substantial role in facilitating the creation of the fund. 
Transit Oriented Structured Funds are currently not being used in the Metro Vancouver context, therefore collaboration between key housing stakeholders will be needed to assess the viability of creating this type of policy tool. It is imperative that the regional government, the 21 local municipalities, the provincial government, non-profits, as well as financial institutions, such as New Market Funds, start the conversation surrounding the capital requirements that will be needed to get the fund started.

Given that the federal government already acts as a lender through the Rental Construction Financing Initiative, both levels of government could contribute to the creation of the fund. Furthermore, financial institutions like New Market Funds could provide the patient capital needed to get the fund off the ground.

The regional government should be the central coordinator. This is because the governance structure is already set up to allow this political body to serve as a forum for discussion between the local governments on matters of regional interest. The eligibility requirements for the fund should be predicated on the prioritization of transit-oriented projects that seek to incorporate rental housing that caters to low and very low-income households, While this type of policy tool will ultimately be a product of extensive stakeholder negotiations, Burnaby could be a champion for the creation of this policy tool which could help to facilitate buy in from other municipal governments. 


\section{APPENDICES}

\section{Appendix A - Interview Questions: Public Sector}

1. What are the most significant barriers that impede the ability of the City of Burnaby to protect and provide affordable rental housing?

a. Do you think the municipality has adequate tools?

2. Some Metro Vancouver municipalities require a one to one rental replacement in areas that already have a significant amount of rental stock.

a. Do you think this is a tool the City should consider using? What would the perceived benefits be?

b. What are some of the biggest challenges associated with this type of policy?

3. What is your experience with developers - what have you heard from them in terms of the challenges they face in building affordable rental housing?

4. What role do you think the municipality could play in facilitating the protection of affordable rental housing?

a. What is the role for upper levels of government?

5. Are you aware of what other municipalities are doing to protect and provide affordable housing?

a. Which programs and policies do you think are working well and how could they be replicated in Burnaby?

b. What are the challenges that are preventing Burnaby from adopting these types of programs and policies?

6. Does the City or Province currently own land near the SkyTrain stations? Could this be leveraged for affordable rental housing creation? If so:

a. What are the potential benefits associated with this?

b. What are the challenges?

7. What is the buffer used for Transit Oriented Development in Burnaby? 


\section{Appendix B - Interview Questions: Private Sector}

1. What do you think the role of the municipality is in providing and protecting affordable housing?

a. What role can a developer play?

2. There are already a number of incentives in place that encourage the provision of affordable rental housing - do you think these are sufficient?

a. What other incentives would encourage you to build affordable rental housing

b. Would tax breaks and/or exemptions help to make a rental project more viable?

3. In your professional experience, what are the main barriers to building and protecting affordable rental housing in Burnaby?

4. Do you feel the planning and development process in Burnaby is efficient and transparent?

a. If not, do you feel it dissuades you from including affordable housing options in a development project?

5. Some municipalities have the ability to require a 1:1 rental replacement in areas that already have a significant amount of rental stock. If this was implemented in Burnaby what would your response be?

a. What are the market implications of this type of policy? Discuss the challenges as well as the opportunities.

b. What could the City do to mitigate any assessed challenges associated with this policy? 6. If public sector land could be leased to the private sector with the intention of building affordable rental housing, would you participate?

a. What are the opportunities and challenges associated with this? 


\section{WORKS CITED}

Addison, C., Zhang, S., \& Coomes, B. (2013). Smart Growth and Housing Affordability: A Review of Regulatory Mechanisms and Planning Practices. Journal of Planning Literature, 28(3), 215-257.

Reconnecting America. (2006). Preserving and Promoting Diverse Transit-Oriented Neighborhoods.

Bay Area TOAH Fund. (n.d). Bay Area TOAH Fund. Retrieved from: http://bayareatod.com/

BC Housing. (n.d.). About: Our Organization. Retrieved from BC Housing: http://www.bchousing.org/aboutus/activities

BC Housing. (n.d.) About: Federal Agreements. Retrieved from BC Housing: https://www.bchousing.org/about/federal-agreements

BC Housing. (n.d.). Community Partnership Initiatives. Retrieved from BC Housing: https://www.bchousing.org/partner-services/funding-opportunities-for-housingpartners/community-partnership-initiative.

BC Housing. (n.d.). Major Projects: Cedar Place. Retrieved from BC Housing: https://www.bchousing.org/partner-services/major-projects/cedar-place

BC Ministry of Community Services. (2008). Revitalization Tax Exemptions A Primer on the Provisions in the Community Charter. Retrieved from Ministry of Community Services: http://www.cscd.gov.bc.ca/lgd/gov_structure/library/community_charter_revital_tax_exe mptions.pdf

BC Ministry of Forests and Range Housing Department. (n.d.) Local Government Guide for Improving Market Housing Affordability. Retrieved from: http://www.housing.gov.bc.ca/pub/market_housing_affordability.pdf

BC Non-Profit Housing Association. (2017). Transit-Oriented Affordable Housing Study: ACTIVITY 1 - Environmental Scan and Literature Review.

Bernick, M., and R. Cervero. 1997. Transit villages in the $21^{\text {st }}$ Century. New York, NY: McGraw-Hill.

Bula, F. (2016, August 29). Seattle Offers Lessons in Helping Renters. The Globe and Mail. Retrieved from: https://beta.theglobeandmail.com/news/british-columbia/cities-searchfor-options-to-easerentalcrisis/article31599625/?ref=http://www.theglobeandmail.com\&). 
Canadian Housing and Mortgage Corporation. (2017). Canadians Get Affordable Housing Help. [Press release]. Retrieved from https://www.cmhcschl.gc.ca/en/corp/nero/nere/2017/2017-11-22-1505.cfm

Canadian Mortgage and Housing Corporation (CMHC). (n.d). Rental Construction Financing Initiative. Retrieved from CMHC: https://www.cmhcschl.gc.ca/en/hoficlincl/moloin/mupr/rental-construction-initiative.cfm

Canadian Mortgage and Housing Corporation (CMHC). (2017). Rental Market ReportVancouver CMA. Retrieved from CMHC: https://www.cmhcschl.gc.ca/odpub/esub/64467/64467_2017_A01.pdf?fr=1523285737753

Carter, T. (1997). Current Practices for Procuring Affordable Housing: The Canadian Context. Housing Policy Debate, 8(3), 593-631.

City of Burnaby. (2011). Committee Report: Application of the Supplemental Community Benefit Density Bonus Program. Retrieved from the City of Burnaby: Retrieved from the City of Burnaby: https://search.heritageburnaby.ca/media/hpo/_Data/_CouncilMinutes_AndReports/Unrestri cted/2010/1-Nov-2010/78370.pdf

City of Burnaby. (2014). City of Burnaby Official Community Plan. Retrieved from the City of Burnaby Planning \& Building Department: https://www.burnaby.ca/Assets/city+services/policies+projects+and+initiatives/communi ty+development/OCP+PDFs/OCP+1998+(full+version).pdf

City of Burnaby. (2014). 2014 Community Benefit Bonus Policy Review. Retrieved from the City of Burnaby: https://eagenda.burnaby.ca/sirepub/cache/2/shdoln5tbctmawrur4ollchg/37700407201804 0418875.PDF

City of Burnaby. (2016). Burnaby Housing Profile - 2016. Retrieved from the City of Burnaby: https://www.burnaby.ca/Assets/Burnaby+Housing+Profile.pdf

City of Burnaby. (2016). City of Burnaby and Province Partner to Develop 180 New Social Housing Units in Burnaby [Press release].

Retrieved from the City of Burnaby: https://www.burnaby.ca/About-Burnaby/News-and-Media/Newsroom/City-of-Burnabyad-Province-Partner-to-Develop-180-New-Social-Housing-Units-inBurnaby_s2_p5570.html

City of New Westminster. (2017). Secured Market Rental Housing Policy New Westminster. Retrieved from the City of New Westminster: https://www.newwestcity.ca/database/files/library/Secured_Market_Rental_Housing_Pol icy_FINAL__Revised_2017.pdf 
City of North Vancouver. (n.d.). City of North Vancouver Official Community Plan Discussion Paper.: Retrieved from the City of North Vancouver: http://www2.cnv.org/CityShaping/papers/Discussion\%20Paper\%20\%200ur\%20Vision\%20of\%20a\%20Complete\%20Community.pdf

City of Richmond. (2016). Committee Report: Affordable Housing Strategy Update - Low End Market Rental Policy Information Backgrounder. Retrieved from the City of Richmond: https://www.richmond.ca/_shared/assets/AffordableHousingLowEndMarketRental4533 8.pdf

City of Seattle Office of Housing (2017). Renter's Guide to the City of Seattle's Multifamily Tax Exemption and Incentive Zoning Programs. Retrieved from the City of Seattle:

https://www.seattle.gov/Documents/Departments/Housing/Renters/MFTE.IZ.RentersGui de.pdf

City of Seattle Office of Housing (2017). City of Seattle MultiFamily Property Tax Exemption Program: 2016 Status Report to City Council. Retrieved from Seattle Office of Housing: https://www.seattle.gov/Documents/Departments/Housing/HousingDevelopers/Multifami lyTaxExemption/2016_MFTE_Annual_Report_with_Attachments-Final.pdf

City of Vancouver. (2007). Official Development Plan Regarding Areas of Real Property in certain RM, FM, and CD-1 Zoning Districts. Retrieved from the City of Vancouver: http://vancouver.ca/files/cov/Rental-Housing-Stock-Official-Development-Plan.pdf

Clayton, F. (1998, November). Economic Impact of Federal Tax Legislation on the Rental Housing Market in Canada.

Coriolis Consulting Corporation. (2012). Metro Vancouver Purpose-built Rental Housing: Inventory and Risk Analysis.

Duncan, M. (2011a). The impact of transit-oriented development on housing prices in San Diego, CA. Urban studies, 48(1), 101-127.

Duncan, M. (2011b). The synergistic influence of light rail stations and zoning on home prices. Environment and Planning A, 43(9), 2125-2142.

Enemark, T. (2017, July 6). Fastest Way to More Rental Housing? Tax Changes. Retrieved from https://thetyee.ca/Opinion/2017/07/06/Tax-Changes-More-Rental-Housing/

Goodman, D. (2018). Goodman Report: 2017 Greater Vancouver Rental Apartment Review. Vancouver: Goodman. 
Hoffman, H. (2011, June 20). Seattle's Multifamily Tax Exemption Program Ensures Affordable Housing. The Seattle Times. Retrieved from https://www.seattletimes.com/opinion/seattles-multifamily-tax-exemption-programensures-affordable-housing/

Hulchanski, David J. (2004) "What Factors Shape Canadian Housing Policy? The Intergovernmental Role in Canada's Housing System," in The State of the Federation 2004 - Municipal-Federal-Provincial Relations in Canada, (R. Young and C. Leuprecht, eds.), Kingston: McGill-Queen's University Press, for the Queen's University Institute of Intergovernmental Relations

Jones, C. E. (2014). Income polarization and the emergence of a low income SkyTrain corridor in Metro Vancouver, 1971-2006 (Doctoral dissertation, University of British Columbia).

Jones, C. E., \& Ley, D. (2016). Transit-oriented Development and Gentrification Along Metro Vancouver's Low-income SkyTrain corridor: Transit-oriented Development. The Canadian Geographer / Le Géographe Canadien, 60(1), 9-22.

Keightley, M. P. (2013). An Introduction to the Low-Income Housing Tax Credit. Congressional Research Service, February 12

Kloepper, K. (2017). On the Wrong Track? Perspectives on Affordable Housing and Transit Oriented Development in Metro Vancouver (Master's thesis, The University of British Columbia, 2017). Vancouver: The University of British Columbia.

Litman, T. (2017). Affordable-Accessible Housing in a Dynamic City. Victoria Transport Policy Institute.

McClanaghan, D. (2010, August). City of Vancouver Rental Housing Strategy Research and Policy Development. Vancouver: McClanaghan \& Associates and The City of Vancouver.

Metro Vancouver. (2012). The Metro Vancouver Apartment Parking Study: Summary Book.

Metro Vancouver. (2012). What Works: Affordable Housing Initiatives in Metro Vancouver Municipalities.

Metro Vancouver. (2014). 2011 Population Density and the Metro 2040 Growth Model

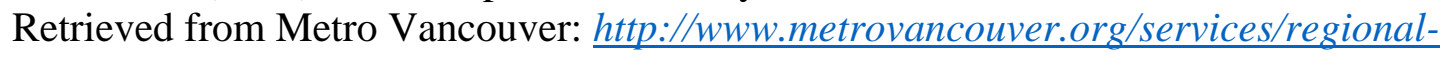
planning/PlanningPublications/140509_RPA_Density_and_Urban_Growth.pdf

Metro Vancouver. (2015). Metro Vancouver 2040: Shaping Our Future.

Metro Vancouver. (2015). The Metro Vancouver Housing and Transportation Cost Burden Study a New Way of Looking at Affordability.

Metro Vancouver. (2015). Regional Affordable Housing Strategy. 
Metro Vancouver. (2016). What Works: Municipal Measures for Sustaining and Expanding the Supply of Purpose-Built Rental Housing.

Metro Vancouver. (2018). Metro Vancouver Housing Data Book.

Naylor, C. (2017). Rentals Versus Condos: Has Burnaby Struck the Right Balance? BurnabyNow. Retrieved from http://www.burnabynow.com/news/rentalsversus-condos-has-burnaby-struck-the-right-balance-1.2246918

New Markey Funds. (n.d.). Home: Fund. Retrieved from New Market Funds: http://newmarketfunds.ca/home/fund

Pollon, C. (2017). Tapping 'Patient Capital' to Fund Affordable Rental Housing. The Tyee. Retrieved from https://thetyee.ca/News/2017/07/26/Patient-Capital-Affordable-RentalHousing/

Pomeroy, S. (2015). Built to last: Strengthening the foundations of housing in Canada. Federation of Canadian Municipalities.

Province of British Columbia. (2018). Homes for B.C.: A 30-Point Plan for Housing Affordability in British Columbia.

Quigley, L. (2010). Preserving affordable housing near transit: Case studies from Atlanta, Denver, Seattle and Washington, DC Columbia, MD: Enterprise Community Partners.

Rayle, L. (2015). Investigating the connection between transit-oriented development and displacement: Four hypotheses. Housing Policy Debate, 25(3).

Revington, N., \& Townsend, C. (2016). Market rental housing affordability and rapid transit catchments: Application of a new measure in Canada. Housing Policy Debate, 26(4-5), 864-886.

Schuk, C. (2009). Overcoming Challenges in Centralized and Decentralized Housing Models: Ontario and British Columbia Compared. Canadian Policy Research Networks.

Seifel Consulting Inc. (2013). Bay Area Transit-Oriented Affordable Housing Fund: Assessment and Lessons Learned.

Statistics Canada. 2017. Burnaby, CY [Census subdivision], British Columbia and Greater Vancouver, RD [Census division], British Columbia(table). Census Profile. 2016 Census. Statistics Canada Catalogue no. 98-316-X2016001. Ottawa. Released October 25, 2017. http://www12.statcan.gc.ca/census-recensement/2016/dp$\mathrm{pd} / \mathrm{prof} /$ index.cfm?Lang=E (accessed November 19, 2017). 
Statistics Canada. 2017. Richmond, CY [Census subdivision], British Columbia and British Columbia [Province] (table). Census Profile. 2016 Census. Statistics Canada Catalogue no. 98-316-X2016001. Ottawa. Released November 29, 2017. http://www12.statcan.gc.ca/census-recensement/2016/dp$\mathrm{pd} /$ prof/index.cfm?Lang=E (accessed March 29, 2018).

TransLink. (2011). Transport 2040.

Trumm, D. (2017, July 19). Dissecting MFTE: 855 New Units Added In 2016 But Rent Limit Jumped $7 \%$ [Web log post]. Retrieved from https://www.theurbanist.org/2017/07/19/mfte-provides-tons-affordable-apartments-usetweaks/

Verrilli, A., \& Raitt, J. (2009). The Use of Chapter 40R in Massachusetts as a Tool for Smart Growth and Affordable Housing Production. Boston: Citizens' Housing and Planning Association and the Metropolitan Area Planning Council Retrieved from http://www. mass. gov/hed/docs/dhcd/cd/ch40r/theuseofch40rin-ma. pdf. 